\title{
National Institute of Justice
}

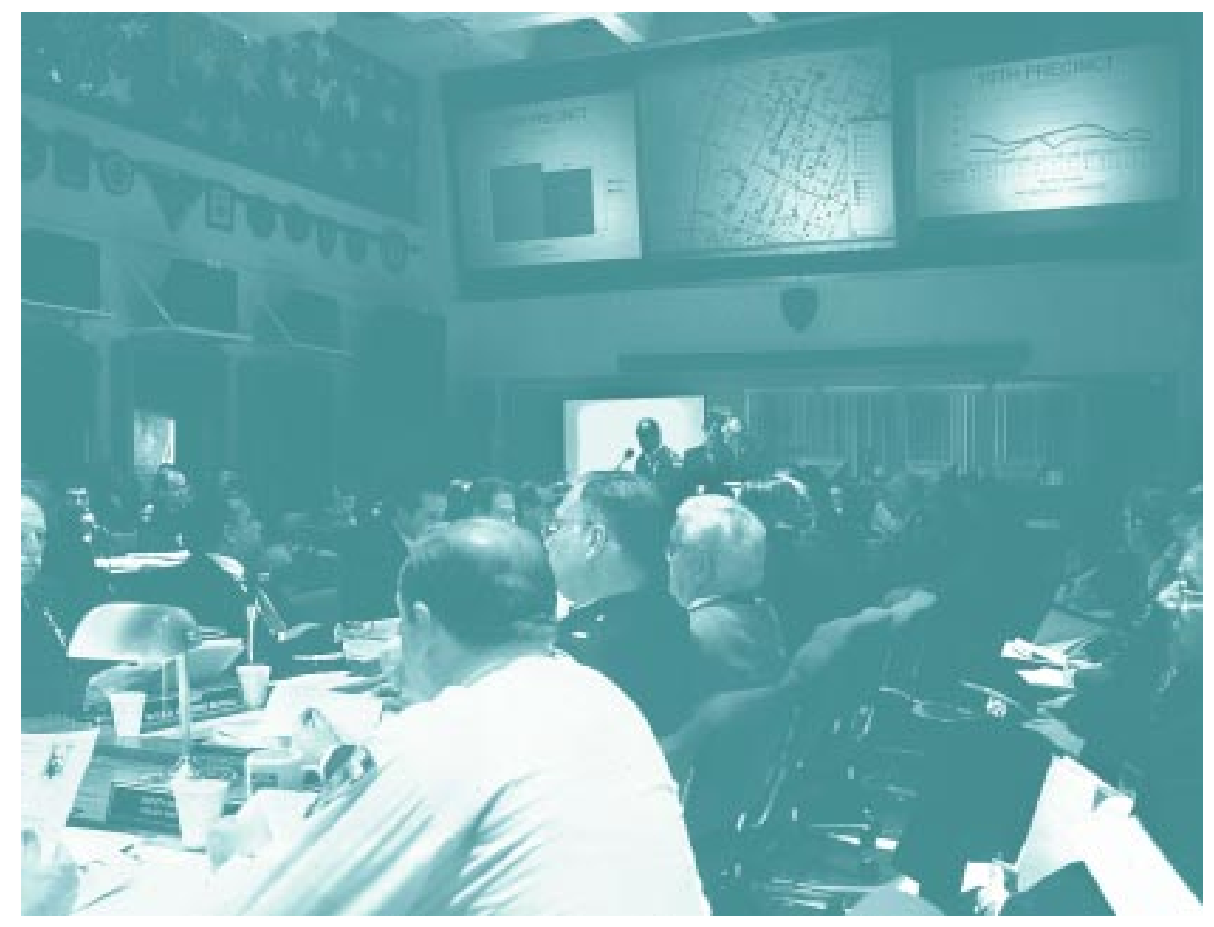

\section{Suppose We Were Really Serious About Police Departments Becoming "LEARNING ORganizaTIONS"?}

\section{Also in this Issuei}

Drug Testing in Criminal Justice: Evolving Uses, Emerging Technologies

The Unrealized Potential of DNA Testing

Looking Backward to Look Forward:

The 1967 Crime Commission Report in Retrospect 


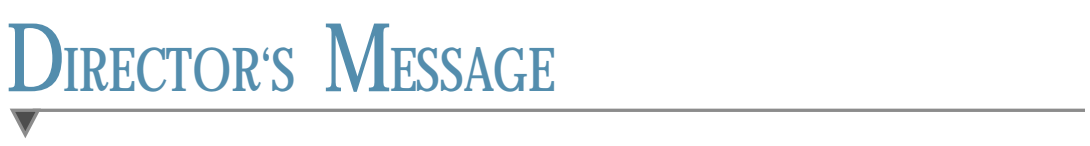

Reviewing the feature articles in this issue of the $\mathrm{N}$ ational Institute of Justice Journal, I was reminded of how numerous and wide-ranging are the concerns of criminal justice professionals. So are the levels at which these concerns are tackled: strategic planning, resource allocation, measuring progress against goals- to name only a few. At one and the same time, day-to-day practices are carried out, agency procedures are followed. $0 \mathrm{n}$ the margin of the day a moment may be carved out for reflection, for gaining perspective by pondering pastactions as a prelude to defining future courses.

The articles on DN A evidence by Victor W eedn and John Hicks and on drug testing by Tom M ieczkow ski and Kim Lersch are rooted in the everyday practicalities dealt with by police, prosecutors, and the judiciary. They illustrate as well the dependence of criminal justice practitioners on the "hard sciences," and our rationale in selecting them for the Journal was to help keep criminal justice professionals in these fields abreast of some of the most advanced technologies and practices in use now and on the horizon.

$0 \mathrm{n}$ the continuum of criminal justice concerns, the issues W illiam $\mathrm{G}$ eller raises in his article on police departments as "learning organizations" seem to lie far from DN A and drug testing. To be sure, police management is no less of a day-today proposition, but this article suggests mentally and momenta rily suspending workaday realities in order to consider broad new management concepts in which research has a key role. The author proposes that police organizations can institutionalize the learning process in the same way as the country's best run businesses. Professor M ark Moore's article on the commemoration of the 30 th anniversary of the President's C rime Commission is more contemplative still. $\mathrm{He}$ suggests that the Commission's vision, which encompassed preservation of liberty and inclusion of social justice within the mission of crime control, still applies, but that today we should embrace an even more ambitious vision of justice - reconstructing social bonds that have been torn apart

Collaboration among the components of the criminal justice system is far more advanced today than in the days of the Commission. Part of moving toward the reality of a "system" is familiarization by each component with the others' concems. This doesn't exclude borrowing practices that seem to work for the other components. So, for example, the concepts elaborated by Bill G eller for police departments could arguably be adopted by prosecutors' offices. It's in the spirit of fostering this kind of "cross training" that we present the current issue of the Journal.

Jeremy Travis

Director

$\mathrm{N}$ ational Institute of Justice

\section{National Institute of Justice Jeremy Travis \\ Director}

\section{NIJ Journal Editorial Board \\ Sally T. Hillsman \\ Deputy Director for Office of \\ Research and Evaluation \\ John L. Schwarz \\ Deputy Director for Office of \\ Development and Dissemination \\ David Boyd \\ Deputy Director for Office of \\ Science and Technology}

Cheryl A. Crawford

Mary G. Graham

Marj Leaming

Michelle-Marie Mendez

Christy Visher

\section{Issue Editor}

Judy A. Reardon

The National Institute of Justice Journal is published by the National Institute of Justice, the research arm of the U.S. Department of Justice, to announce the Institute's policy-relevant research results and initiatives. The Attorney General has determined that publication of this periodical is necessary in the transaction of the public business required by law of the Department of Justice.

Opinions or points of view expressed in this document are those of the authors and do not necessarily reflect the official position of the U.S. Department of Justice.

The National Criminal Justice Reference Service (NCJRS), a centralized national clearinghouse of criminal justice information, is sponsored by the Office of Justice Programs agencies and the Office of National Drug Control Policy. Registered users of NCJRS receive the National Institute of Justice Journal and NCJRS Catalog free. To become a registered user, write NCJRS User Services, Box 6000, Rockville, MD 20849-6000, call 800-851-3420, or e-mail askncjrs@ncjrs.org.

The National Institute of Justice is a component of the Office of Justice Programs, which also includes the Bureau of Justice Assistance, the Bureau of Justice Statistics, the Office of Juvenile Justice and Delinquency Prevention, and the Office for Victims of Crime. 


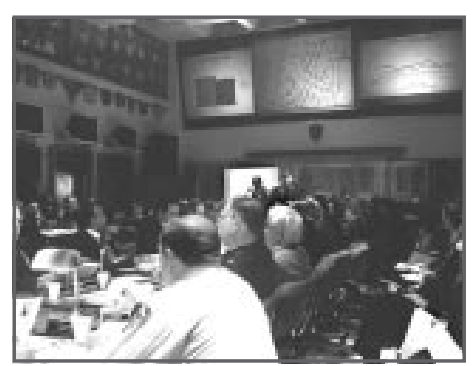

Suppose We Were Really Serious About Police

Departments Becoming “Learning Organizations”? See page 2

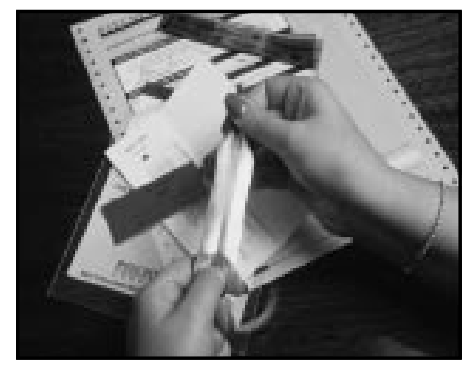

Drug Testing in Criminal Justice See page 9

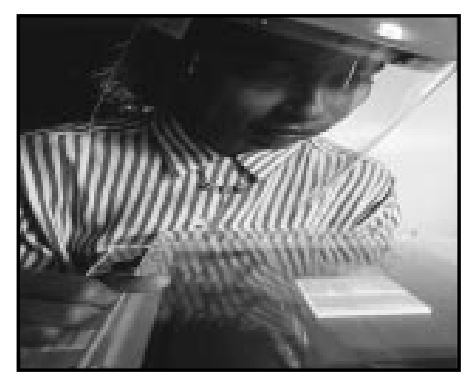

The Unrealized Potential of DNA Testing See page 16

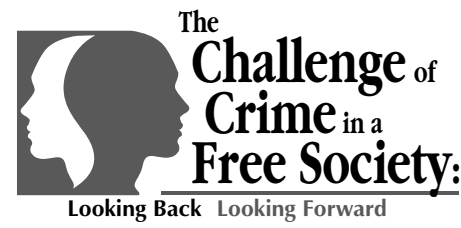

Looking Backward to Look

Forward

See page 24

\section{Features}

Suppose We Were Really Serious About Police Departments Becoming

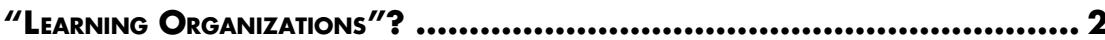

Drug Testing in Criminal Justice: Evolving Uses, Emerging Technologies ..... 9

The Unrealized Potential of DNA Testing 16

Looking Backward to Look Forward: The 1967 Crime Commission Report in Retrospect

\section{Research Preview}

Comparing Drug Purchase and Use Patterns in Six Cities

EvenTS

NIJ IN the Journals

Recent NIJ Publications

Final Reports

SOLICITATIONS

New \& Noteworthy

On the cover: At a New York City Police Department Compstat meeting. Photo courtesy of the New York City Police Department Photo Unit. 


\section{Suppose We Were \\ by William A. Geller* \\ Introduction: The risks of not learning}

Really
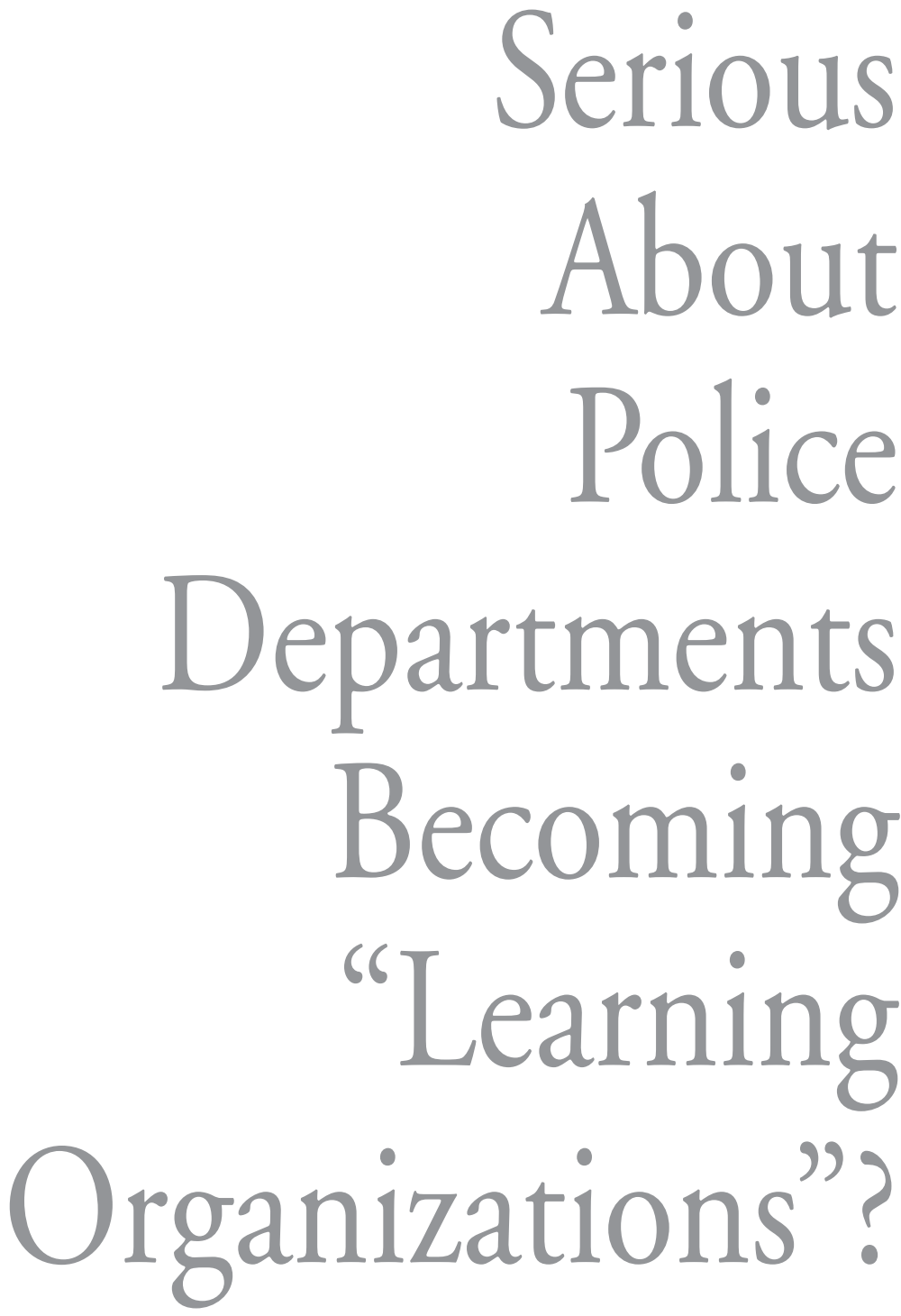

An African proverb goes, "No one tests the depth of a river with both feet." Yet thoughtful police sometimes wonder if their department is an exception to this rule. They watch bewildered and despairing as their organization leaps from one tactic and program to another-rarely bothering to conduct a meaningful feasibility study or figure out what worked and what didn't work and under what conditions the last time a similar problem was tackled.

How many departments have ever jumped into a program with both feet, sunk in the muck, and then compounded the problem by failing to learn from the experience? How would Aleksandr Lebed, the retired general who aspires to be the next President of Russia, size up such departments? Commenting recently in The New York Times on the propensity of Russia to lurch from one government to another, he said: "There's got to be a time when you stop stepping on the same rake."

When traditional tactics seem defunct, why do police, other criminal justice agencies, and politicians seem to have such a hard time cutting their losses—such a hard time grasping columnist Molly Ivins' "First Rule of Holes": "When you are in one, you should stop digging!"

We are confronted with a simply stated, yet daunting, challenge: Can our police and sheriffs' departments find ways to work smarter, not just harder? Is there a practical, day-to-day role for research and analysis in helping collaborative organizations succeed more frequently and more fully? Can we begin to institutionalize the organizational learning process, just as our Nation's best run companies do, so that our departments can serve and strengthen their communities more effectively, more efficiently, and more legitimately?

*William A. Geller, J.D., is Director of Geller \& Associates, which specializes in consulting on diverse partnerships for public safety. He is grateful to Phyllis McDonald of the NIJ staff for her guidance in preparing this article. This article was adapted and abridged from the author's presentation at an NIJ "cluster conference" of participants in the Institute's locally initiated research partnerships. The conference was held in Washington, D.C., on January 24, 1997. 
I'd like to offer some tentative thoughts on the benefits for police departments of becoming "learning organizations," the obstacles to doing this, and the steps departments might be able to take to foster institutional learning as a continual part of doing business.

For starters, what do we mean when we talk about a "learning organization"? The concept was described in detail by management consultant Peter Senge, but his general definition will suffice. "In Chinese," he writes, " 'learning' literally means 'study and practice constantly.' This, then, is the basic meaning of a 'learning organization'-an organization that is continually expanding its capacity to create its future."

\section{Benefits}

A learning organization becomes smart enough to decipher the useful lessons an experience or study offers. It also becomes smart enough not to overgeneralize. As Mark Twain cautioned:

We should be careful to get out of an experience only the wisdom that is in it, and stop there, lest we be like the cat that sits down on a hot stove lid. She will never sit down on a hot stove lid again, and this is well; but she will never sit down on a cold one either. ${ }^{2}$

Learning not to overgeneralizelearning to diagnose more accurately-is one possible benefit. Police departments might avoid generalizing, for instance, about the kinds of community organizations that can become trusted allies.

Pinning down in a demonstrable way, with supporting data, what works in

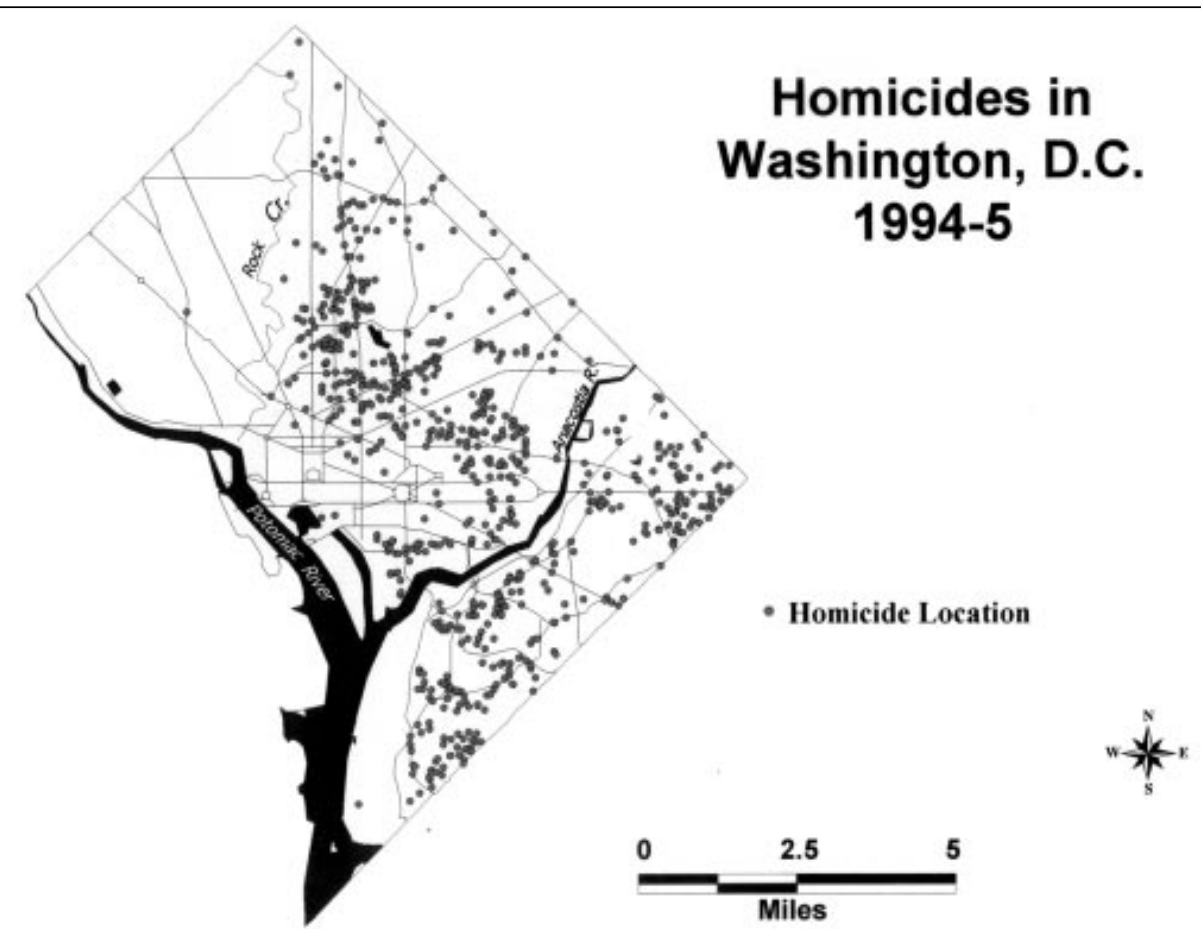

Sources: 1990 Census of Population and Housing; Washington Metropolitan Police Department; National Institute of Justice Crime Mapping Research Center.

Computerized mapping is a tool to help police learn about the spatial and temporal dimensions of crime.

battling crime and disorder and in building community justice and peacekeeping capacity is another benefit. Such knowledge can improve police morale, increase public esteem for the department, and help the organization and community better deploy resources.

Benchmarking is still another benefit. It involves learning enough about what is average and what is excellent in an industry that standards can be articulated as the object of professional aspiration. Police departments could also learn to devise meaningful measures of "risk": such measures as how soon and how hard crime comes back under different conditions after a particular effort to suppress it.

As police departments experiment with and assess the efficacy of strategies such as community policing, problem-oriented policing, and restor- ative justice, they can learn better to distinguish between "conceptual failures" and "implementation failures." If an initiative failed because the basic strategy was flawed or because the approach works only in very limited circumstances, that is important for the entire industry to know. But if a concept such as community policing is found wanting, it may also be because, as police administrator-turnedacademic and artisan Wayne Kerstetter quipped, "We didn't try it, and it didn't work." That is an "implementation failure."

Thus, a learning organization capitalizes on its own and others' experiences_-successes as well as failures - to continually hone strategies, tactics, operations, and networks of collaborators. A learning organization learns to measure what really matters, for it understands that what we measure is taken more seriously. ${ }^{3}$ 


\section{Suppose We Were Really Serious}

\section{Obstacles}

If this is so good, why isn't every police department already what the management gurus would call a "learning organization"? There are a variety of impediments, including:

- Skepticism about research as ivy tower and impractical.

- Resistance to cooperating with outside researchers because too often they have failed to provide feedback soon enough to assist practitioners. This is research at versus research with a police department.

- Distrust of evaluation research because of the blisters that linger from the last time the department was burned by a badly conducted study.

- Skepticism that research findings developed in another jurisdiction have any application at home-an idea captured with the oft-heard assertion, "My city is different." Consider the heavy burden of the "truly unique" person: As they say, he can't learn from the mistakes of others, yet he won't live long enough to make them all himself!

- The myth that encouraging critical thinking among the rank and file will undermine necessary paramilitary discipline ("Yours is not to reason why, yours is but to do or die"). ${ }^{4}$

- The belief that thinking inhibits doing, an idea expressed in the first century B.C. by the Greek philosopher Publilius Syrus. "While we stop to think," he said, "we often miss our opportunity." But this is the same guy who declared that "for a good cause, wrongdoing is virtuous," so consider the source.

What examples might lead one to think that the person of action is someone who does not stop to learn? Surely the example could not be an NFL football team. Those beefy gladiators spend far more time watching game films and practicing how to improve than they spend on the field. Yet NFL players have something most police departments don't—or at least don't avail themselves of: a powerful support team of thinkers, analysts, and teachers. The average police department research and development unit, as sociologist $\mathrm{Al}$ Reiss pointed out, does nothing remotely resembling either research or development as those concepts are commonly understood in industry and the professions. ${ }^{5}$ So another obstacle is the mistaken assumption that, because we have a unit called "R\&D," we've "got it covered."

- The indoctrination process of most police departments also inhibits employees from contributing meaningfully to organizational selfappraisal. As Hans Mattick observed several decades ago, "You can't train an aviator in a submarine." If police recruits are taught not to think critically, what a surprise that they don't know how to respond to their bosses' challenge to be innovative, take calculated risks, and otherwise contribute to the organization's continual reinvention!

A police department that denigrates rank-and-file thinking about the organization's basic business establishes a culture likely to ridicule or demean those who would take time from routine activities (random preventive patrol, etc.), which police have taught themselves, politicians, and the public constitutes real and tough police work. Herman Goldstein worries that the "daily activities involved in conducting research may be viewed ... in the police subculture as 'goofing off.' ", How many problem-solving brainstorming meetings have there been that a supervisor adjourned with the exhortation, "O.K., now let's get back to work!'? Just once, I wish an officer would retort, "I thought we were working just now!"

- Another impediment is reluctance to have cherished views challenged. An astute observer of the process wrote: "Even the best of us are prone to making decisions based on biases and mindsets. Worse, we cling to comfortable beliefs. As Francis Bacon pointed out, 'We prefer to believe what we prefer to be true." " In traditional organizations, success is often considered not rocking the boat.

- A related obstacle is confronted by those who might be assigned to "rock the boat." "It is hard to engage in organizational selfcriticism," Goldstein observes, "knowing one must continue to work with the officers whose current efforts are criticized." 8

- There often seems to be insufficient time for employees to reflect on their work, and a lack of time, authority, resources, and skills for them to conduct research.

- Finally, there's the ancient and still mighty obstacle to innovation: People usually fear change. Not everyone does, of course. Aleksandr Lebed uses a litmus test to determine whether Russia's "new rich" are open to change: "When I greet a group of entrepreneurs," he said, "I hail them, 'Hello, crooks!' If they take it O.K., then they are not hopeless. If they beat their breasts and deny it, then they are incorrigible."

\section{Fostering the learning organization}

Police departments didn't just develop their "learning disorders" overnightthey've worked at it for a long time! So what is one to do to begin to turn the tide? Here are some tentative suggestions for fostering an organizational culture that encourages continual learning. 
One idea is to create an R\&D unit that actually does research and development, has a respectable budget, and is run by someone who understands R\&D. Reiss dropped the gauntlet for American policing this way:

Research means empirical investigation that describes and explains how things behave and change their behavior; development means the actual implementation [and testing under field conditions] of models that demonstrate whether an intervention works in a predictable way. Police organizations essentially lack research and development units understood in this way. The research unit of most police organizations typically is responsible for providing a statistical description of the organization and its inputs and outputs. Rarely does it undertake research that might lead to development, and the department typically makes no provision for development. $^{10}$

Reiss sharply contrasts the Nation's defense industry, which spends a sizable portion of its budget on R\&D, with how policing-our domestic defense industry-deploys its budget between operations, learning, and invention. Police departments could consider establishing budget and operational routines in which a percentage of the operating costs of new initiatives are allocated to internal and/or external program assessment.
One practical way to increase the chances that an R\&D unit will become a useful internal source of learning and an effective broker between the department's leadership and universities and other external think tanks is to select as the $\mathrm{R} \& \mathrm{D}$ director someone with capacity and respect as a manager of applied research. More and more we are finding examples of police chiefs picking people like

this. Yet how many departments' R\&D units are headed by-or at least have one staff member-who is a well-trained researcher with the appropriate academic credentials? A related, perhaps controversial step is to hire and develop sworn and civilian personnel for units other than R\&D and crime analysis who have experience in learning through applied research and program assessment. Who says they couldn't be good cops?

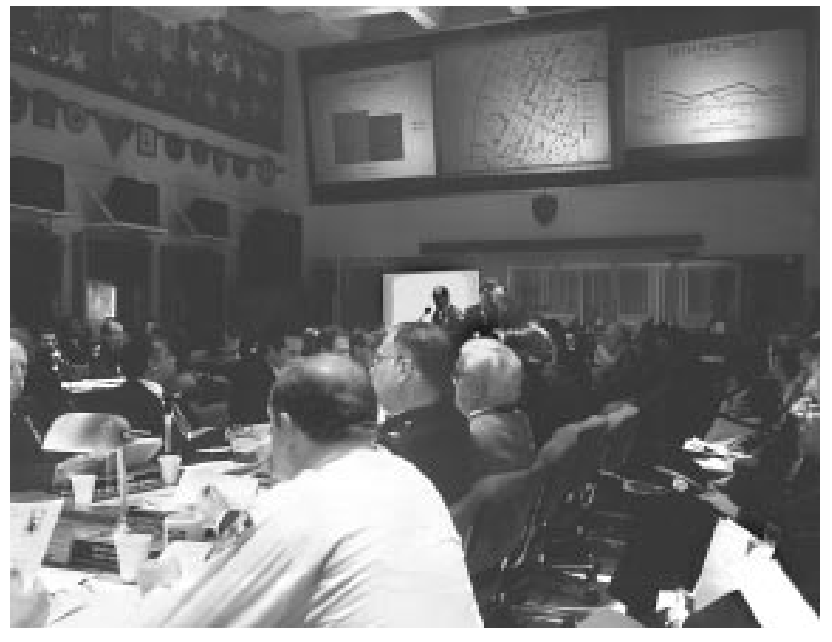

A second structure or process to foster learning might be crime analysis that spans work units. Crimes, offenders, and victims often migrate beyond precinct and even jurisdictional boundaries. Departments that have created an infrastructure of geographical crime analysis powerful and global enough to track crime patterns have increased their ability to spot and respond to problematic patternsand to recruit allies.

A third process to foster learning can involve senior police officials reducing turf battles between departmental units. In its Compstat process, the New York City Police Department holds monthly meetings to discuss progress against crime and disorder patterns, and all units that could reasonably be held accountable for attacking a particular crime problem have senior representatives attend.

A way had to be found to cut through the legendary reluctance of some units

At the New York City Police Department's Compstat ("computer comparison statistics") meetings, uniformed officers and civilians convene at police headquarters, where statistics on crime levels are presented and commanders answer questions about their areas. Sessions like these can foster learning by helping departmental units work together to better control crime.

Photo courtesy of the New York City Police Department Photo Unit. 
to cooperate and share knowledge with one another. Their collaborative reluctance often reminds me of a wisecrack by Abbie Hoffman at his arraignment in the Chicago Conspiracy Trial: "Conspiracy?!" he asked the judge incredulously, looking at his codefendants: "We couldn't agree on lunch!” In the NYPD a senior official, with authority over all of the represented units, attends the monthly meetings and can, if necessary, lower the boom on leaders of units who unjustly hoard information or expertise.

A fourth idea is to take a "talent inventory" of sworn and civilian employees' research, analytic, graphic arts, public speaking, and writing skills. Knowing and showing what the work force's collective capacity is to learn from experience and share the lessons learned in the organization, in the profession, and in the community can help create useful internal and external pressures to deploy those skills. Why ask police em-

ployees to "check" their brains and adult problemsolving skills at the door when they come to work? Must imagination be the enemy of discipline and honor?

Fifth, police depart-

As Multnomah County,
Oregon, District Attorney Mike
Schrunk observed, "In
managing or collaborating
well, feedback is the
breakfast of champions."
ments might take a talent inventory of community groups and other key community institutions. Police may be surprised to learn about the range of skills their community has and would willingly deploy to strengthen neighborhoods and collaborate with police. Community organizations may have as members accountants, engineers, public health specialists, educators, writers, lobbyists, public relations experts, social workers, urban anthropologists, lawyers, business managers, inventive entrepreneurs, sociologists, architects, and builders. Universities will be full of talented analysts - although the department and community of course have to be cautious consumers and pick people who will offer practical, constructive criticism and assistance. Banks and other service organizations, as well as merchants' and manufacturing organizations, will have all kinds of analytic skills they may be willing to share, particularly skills in strategic planning to identify and counter external threats to achieving organizational missions.

A sixth idea is to foster learning by organizing police work around problem solving and taking seriously the "SARA" process (scanning, analysis, response, and assessment of results) for confronting problems. Managers and groups of problem-focused officers, working with the community, should devise team problem-solving procedures to guide their work. Routines can be developed, including flexible checklists for supervisors and community organizers, to ensure that problem solvers don't cut corners that would weaken the department's or community's

capacity to make a difference.

One specific device that many police departments find useful for helping officers brainstorm problems and make better use of lessons they've learned is the "problem advisory committee." As part of the routine of problem solving, police officers meet with a panel of their peers to describe the problem, brainstorm its dimensions and its vulnerability to countermeasures, and consider the comparative value for different stakeholders of alternatives to the planned interventions.

A seventh possible process is to "prime the pump" of critical thinking and to control the monster of "groupthink" through devices such as a “designated devil's advocate." We need structures and procedures in police departments that invite reflection and questioning of assumptions. The designated devil's advocate is a technique that some private-sector organizations have used to craft a culture that undermines groupthink.

Groupthink inhibits critical assessment of majority views. The designated devil's advocate involves charging someone who will be attending a meeting to look for reasonable opportunities during that meeting to speak up and challenge the assumptions and reasoning of the other participants. This can be a useful way to more broadly define "employee loyalty" in organizations not accustomed to peer or-God forbidsubordinate questioning of the status quo.

An eighth structural suggestion is to use middle managers to facilitate critical thinking. If, as many public- and private-sector organizational leaders and consultants suggest, the middle manager is an increasingly superfluous and even counterproductive cog, why not give him or her something useful to do? ${ }^{11}$ How about taking advantage of their "boundary spanning" role in the organization-nestled between the policymakers and those responsible for implementing the policy? Why not charge them with facilitating critical thinking about the efficacy of policies and implementation?

If we were really serious about this, the middle managers' performance rating might depend to a significant extent on how effectively they inspire their units and the community to 
constructively criticize and improve the police department. So a ninth structural idea is to explicitly include as part of individual and unit performance ratings the employees' accomplishments in holding current practices up to the prism of industry benchmarks and in helping to forge progress. Does this sound like the Carpenter's exhortation to love thine enemies?

If so, it gets worse, for I offer a tenth structural suggestion to institutionalize the bottom-up appraisal of organizational performance: Invent an employee suggestion program that really works! Consider the example of a midsized manufacturing company where the president was chagrined that he was getting an average of only one useful suggestion per year from each factory worker. He decided to pursue the world standard, held at the time by a Japanese company, of one per week. Two years later, he had succeeded.

What did he do? Unable to pay for the quantity of suggestions he needed, he instituted two stringent procedures and steadfastly stuck by them. The first was that every employee who offered a suggestion would get a reply as to whether the idea was a good one within twenty-four hours. The second rule was that, if the idea was considered good, it would either be implemented - or at least the process for implementing it would commencewithin seventy-two hours of the suggestion. ${ }^{12}$ No big cash bonuses. Just the insight that, as Multnomah County, Oregon, District Attorney Mike Schrunk observed, "In managing or collaborating well, feedback is the breakfast of champions."

My eleventh thought on the subject is that we convincingly show police employees that at least some prior research has had practical benefits for police departments and for them as individuals. It is possible to really cap- ture their attention if we can show that research has contributed to officer safety and the reduction of their career risks.

The spouse abuse studies-in Minneapolis and the replication sites - had a demonstrable and largely salutary impact on arrest policy, even if there was something of a rush to policy after the first widely publicized findings. And the studies of preventing homicide and other crimes of violence by going "upstream" and attacking precursor crimes have had a significant impact. An example is George Kelling's case study of how the New York City Transit Police, by, among other steps, preventing "farebeating," excluded from the subways people who would commit armed robberies and other serious crimes. ${ }^{13}$

A twelfth step in this plan for the recovery of the learning-disabled organization is to continue and expand police-researcher partnerships such as those sponsored by the National Institute of Justice. Such partnerships allow for a sensible division of labor and, if we're lucky, stimulating collaborations that inspire ever better work.

Finally, a baker's dozen thirteenth idea: If a police department finds a researcher it really trusts, the department could contract with him or her part-time to serve as a research "broker"- to help the agency become a better consumer of other researchers' and advisers' services. ${ }^{14}$ Some agencies have acquired this kind of capacity by employing a criminologist to run their planning or R\&D units.

Structural and procedural steps such as these may hold promise of helping police departments learn to learn. If so, our Nation's neighborhoods can be the beneficiaries, for we shall come closer to meeting a fundamental challenge that NIJ Director Jeremy Travis has presented for the criminal justice field and for his colleagues at the Institute— to "ask tough questions and provide honest answers." Doing so requires a fair amount of "stick-toitiveness," of course. As one wit recalled the story, "It was Junior's first day in school, and when he got home his mother asked, 'Did you learn anything today?' 'No,' he replied, 'I have to go back tomorrow.'"

\section{Notes}

1. Senge, Peter M., The Fifth Discipline: The Art and Practice of the Learning Organization, rev. ed., New York: Currency Doubleday, 1994:xv, 14.

2. Quoted in Geller, William A., and Guy Swanger, Managing Innovation in Policing: The Untapped Potential of the Middle Manager, Washington, D.C.: Police Executive Research Forum, 1995:138.

3. See Brady, Thomas V., Measuring What Matters: Part One-Measures of Crime, Fear, and Disorder, Washington, D.C.: U.S. Department of Justice, National Institute of Justice, December 1996; and NIJ Director Jeremy Travis's introduction.

4. See Tom Peters' assertion that successful military units and operations often depend on critical thinking and, at times, on responsible, courageous disregard of orders (quoted in Geller and Swanger, Managing Innovation in Policing, 37-38).

5. Reiss, Albert J., Jr., "What Is 'R\&D' Really?' in Local Government Police Management, ed. William A. Geller, Washington, D.C.: International City/County Management Association, 1991:339.

6. Goldstein, Herman, ProblemOriented Policing, New York: McGraw-Hill, 1990:163. 
7. From Jones, Morgan D., The Thinker's Toolkit: 14 Skills for Making Smarter Decisions in Business and in Life, New York: Times Business, 1995.

8. Goldstein, Problem-Oriented Policing, 163.

9. Swarns, Rachel L., "Unlikely Meeting of Minds: Lebed Meets the Donald," New York Times (national edition), January 23, 1997:A7.

10. Reiss, "What Is 'R\&D' Really?" Goldstein, Problem-Oriented Polic- ing (pp. 161-163), makes similar observations.

11. See Geller and Swanger, Managing Innovation in Policing; Kanter, Rosabeth Moss, "The Middle Manager as Innovator," Harvard Business Review (July-August 1982):92-105; and Tobin, Daniel R., Transformational Learning: Renewing Your Company Through Knowledge and Skills, New York: John Wiley and Sons, 1996.

12. Geller and Swanger, Managing Innovation in Policing, 140-141.
13. Kelling, George L., and Catherine M. Coles, Fixing Broken Windows: Restoring Order and Reducing Crime in Our Communities, New York: Free Press, 1996.

14. For a groundbreaking study of why many municipal agencies have difficulty effectively learning from their expert consultants, see Szanton, Peter, Not Well Advised: The City as ClientAn Illuminating Analysis of Urban Governments and Their Consultant, New York: Russell Sage Foundation and The Ford Foundation, 1981. 


\section{Drug Testing in Criminal Justice:}

$\mathrm{W}$ hen the term "drug testing" is used today, it generally involves certain assumptions about the types of illicit substances tested and the type of technology employed. Usually, both speaker and listener are referring to detection of one of the major illegal psychoactive drugs such as cocaine, heroin, marijuana, or LSD. And usually both have in mind urinalysis as the testing method. Certainly, for most of the history of drug testing, these drugs have been the ones most frequently subjected to testing, with urinalysis the standard procedure. So the assumptions would be based on fact. But as drug testing as a fairly routine procedure enters its third decade, the assumptions may no longer reflect reality because the types of

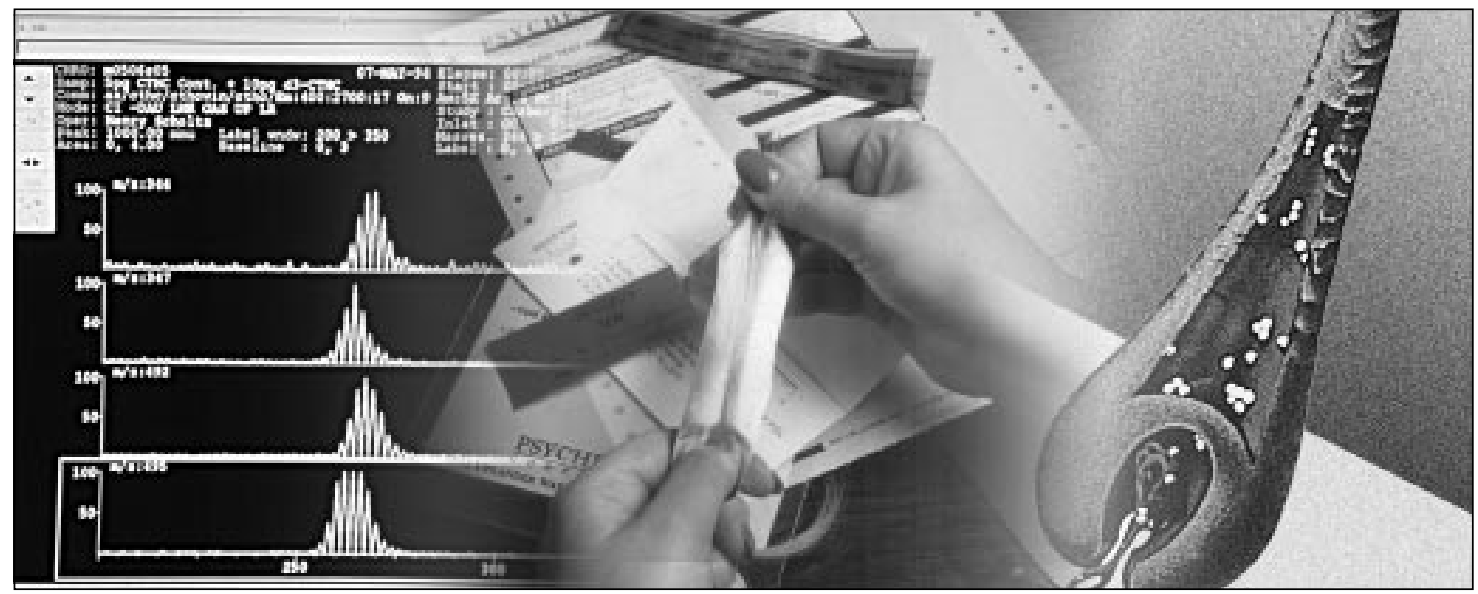
drugs attracting the most interest are changing, and the technology to detect them is evolving to meet new needs.

These changes can best be understood in historical perspective. Looking at the long view makes it easier to see how and why they occurred. A review of the evolution of drug testing

\section{Evolving Uses, Emerging Technologies}

\author{
by Tom Mieczkowski and Kim Lersch*
}

and its applications will demonstrate its growing usefulness. In large measure these applications have resulted from the continuing refinement of testing technologies. Some of these advances, now in the development stage, show promise of making drug testing even more efficient and effective and for extending the number and type of uses for this valuable criminal justice tool.

\section{Current role of drug testing}

Because the use of toxins (or poisons) to inflict harm is an ancient aspect of human misconduct, so are criminological investigations to detect them. As part of these investigations, toxicological analysis retains an important role, but the focus has changed in recent years. Public concern over the use of illegal psychoactive drugs, plus heavy reliance on policing agencies to enforce drug laws, have created a

\footnotetext{
*Tom Mieczkowski, Ph.D., is a professor in the Department of Criminology at the University of South Florida. Kim Lersch, Ph.D., is an assistant professor in the Department of Criminology at the University of South Florida.
} 


\section{Drug Testing in Criminal Justice}

new and enhanced role for toxicological testing in the past 20 years.

Today testing has several uses in the criminal justice system, but the one of most immediate concern to practitioners is detection of illegal drug use by people in custody. Within that context, drug testing can take place at several points in processing offenders, and it has several purposes: to obtain information about the frequency of drug use in particular populations, to gather evidence for use in criminal proceedings, to determine offenders' eligibility for various dispositions and programs (such as treatment), and to ensure the drug-free status of convicted offenders. (See "Uses of Drug Testing in Criminal Justice Practice.”)

\section{The evolution of drug- testing technology}

For most of the past 20 years, the term "drug testing" has been synonymous with urine testing, which remains by far the method of choice in most criminal justice institutions. Several advances in technology have made urinalysis more efficient and effective over the years.

\section{USES OF DRUG TESTING IN CRIMINAL JUSTICE PRACTICE}

\section{Epidemiological analysis}

C riminal justice agencies may test people in custody because they wish to find out the incidence and prevalence of substance abuse. $\mathrm{No}$ attempt is made to match the individuals tested with the test results, so there is no punishment The aggregated results can provide data for planning and evaluation. A major example of this type of use is the Drug Use Forecasting (DUF) program of the $\mathrm{N}$ ational Institute of Justice. ${ }^{1}$

\section{Forensic testing}

People in custody or under suspicion may be tested to find out whether they have consumed a particular drug. The most familiar example is the determination of whether someone operating a motor vehicle is "driving under the influence" (DUI) of alcohol or intoxicating drugs. The results of such forensic (evidentiary) testing can be used as evidence in criminal proceedings. (For DUI suspects, field testing by breath analysis detects blood alcohol levels, but for many of the popular drugs of abuse, no functionally equivalent procedures a re rea dily a vailable.)

\section{Diagnostic or dispositional testing}

Drug testing may be conducted to evaluate the suitability of a rrested or incarcerated people for various dispositions or their eligibility for or referral to particular types of detoxification or treatment Such testing may be done as part of an a rrestee intake health screen, to determine which people entering jail or prison currently are drug users, and what types they use. The results may also be used to determine eligibility for specialized programs such as drug courts, or for participation in diversion programs in which charges are dropped if the offender meets the requirement of drug abstinence. ${ }^{2}$

Arrestees who are released before further criminal processing may be subjected to this type of testing. Pretrial testing includes the requirement that continued drug use is grounds for revoking release.

\section{Compliance monitoring}

All people convicted of crime must submit to a drug test on demand. This category includes those who are incarcerated, those who have been convicted and released into the community on probation, and those on other types of community release. For anyone under community supervision, failure to maintain drug abstinence violates the terms of release or probation.

There are several reasons for the use of drug testing to monitor abstinence in this population. In the case of convicted offenders released into the community, one important rationale is public safety. In addition, drug testing may also help motivate offenders to desist from drug use simply because they do not wish to risk their release status by failing a test.

\section{Notes}

1. N ow in its 10 th year, DUF tests a rrestees in numerous urban areas nationwide, using interview $s$ and ta king urine specimens. Recently rena med A rrestee Drug Abuse M onitoring (ADAM), the program is being expanded beyond the current 23 sites. Sampling procedures are being refined, and the use of the data for conducting research into the drugs-crime nexus will be expanded. See 1996 Drug Use Forecasting: Annual Report on Adult and Juvenile Arrestees, Research Report, W ashington, D.C.: U.S. Department of Justice, N ational Institute of Justice, June 1997.

2. A good example of the use of drug testing to assess the needs and monitor the behavior of drug-involved offenders is the $\mathrm{N}$ ew 0 rleans Diversion Program. See M ieczkow ski, Rosemary M umm, and Harry F. Connick, "The Use of Hair Analysis in a Pretrial Diversion Program in N ew 0 rleans," International Journal of 0 ffender Therapy and Comparative C riminology 39(3) (1995):222-241. 
Chromatography. The molecules of different substances move at different rates and thereby create distinctive patterns that allow them to be distinguished from one another. This property is the basis of the testing method called chromatographic separation.

Essentially, the molecules of different substances, when placed on a surface, separate from one another and form characteristic patterns or bandings.

Developed at the turn of the century, chromatographic separation began in the 1960 s to be widely used for screening (initial) tests to detect psychoactive drugs. In the early form, thin-layer chromatography (TLC), the unknown sub-

stance was

placed in a

tion and applied

to a paper, caus-

ing bands of dif-

ferent lengths to

appear. When

subjected to an-

other chemical,

identifying

(chromatically

also appeared.

Analysis of the

bands and the

colors permitted

identification of

the substance. chemical solu-

distinct) colors confirmatory test is gas chromatography/mass spectrometry (GC/MS).

When chemical analysis to detect psychoactive drugs was first used in a relatively routine matter-in the late 1960s and early 1970s - the procedures used were TLC for screening, coupled with GLC as a confirmatory process (if one was used). ${ }^{2}$

Immunoassays. A major technical development in the 1970s, the immunoassay procedure represented an important advance over TLC. This method uses certain chemical characteristics of substances to detect and label specific drug compounds. Three versions widely used for screening are permit relatively high accuracy in the screening test without the use of confirmatory tests. (When confirmation of an immunoassay is required, usually GC/MS is used.) Programs like DUF have become practical because of the development of this type of technology.

\section{The growth of interest in drug testing}

Routine biological testing to identify drug use is a recent phenomenon. For example, only in the past decade has drug testing to ensure abstinence as a criterion for probation eligibility become a major development and a practice universally adopted throughout the United States. Advances in testing technology have been a driving force in extending the applications of drug testing, but these forces also include shifts in patterns of drug use, rising public concern, and evolving public policy.

Increased drug use provides an impetus. The first use of drug testing as a tool for detection among deviant, addicted populations does not and required interpretation by experts, but chromatography subsequently became highly sophisticated and exact. Two new procedures, high-performance liquid chromatography (HPLC) and gasliquid chromatography (GLC), are a major advance over the original TLC. But like TLC they are slow, and they are also expensive. Thus, they are generally used only to confirm the results of a screening test. ${ }^{1}$ The "gold standard" enzyme multiplied immunoassays $\left(\mathrm{EMIT}^{\mathrm{TM}}\right)$, fluorescence polarization immunoassay (FPIA), and radioimmunoassay (RIA).

The procedure increases the specificity $^{3}$ and reliability of screening. It also lowers costs and decreases the time required, in part because it is readily adaptable to mechanization, allowing large-scale processing. Immunoassays appear in the research literature until the late 1960s. ${ }^{4}$ In the 1970s it was unusual to find programs that routinely conducted testing to identify drug use. In the cases reported in the literature of that period, testing was done exclusively to measure the effectiveness of treatment. Of these, very few instances were found in which drug testing (through urinalysis) was conducted to assess the prevalence of 


\section{Drug Testing in Criminal Justice}

drug use or to verify claims of drug abstinence by people in custody. Evidence of the use of drug testing for other purposes-epidemiological analysis, dispositional decisionmaking, general monitoring of drug-involved criminal offenders, or routine testing of people on probation or other forms of community release-is not found in the literature.

Greater interest in testing to detect substance abuse in certain populations arose in response to reports of increased levels of drug use and the heightened public discussion that followed. By 1977 the first use of urinalysis to evaluate the drug status of people in direct custody (in this instance, arrestees in jail) was reported in the research literature, ${ }^{5}$ and by the early 1980s came the first research using urinalysis to assess the drug status of "unapprehended street criminals."

The move toward "aggressive" testing. During the Reagan administration, drug testing as a generally acceptable technological application received its greatest impetus. The administration's widespread program of testing employees of Federal agencies not only gave the issue of drug testing greater visibility, it also highlighted the availability of the technical capability to conduct large-scale drug screening at relatively low cost.

By the close of the 1980s, the move to increase drug monitoring via testing within the criminal justice system had gained considerable momentum. With the development of rapid, costeffective drug testing the idea of a criminal justice-based drug monitoring system became more realizable. As aggressive drug testing became more acceptable, the idea gained currency. By 1989 the newly established Office of National Drug Control Policy recommended "comprehensive use" of drug testing for virtually all categories of people in the criminal justice system.

\section{Current applications in criminal justice}

Today, as a result of the comprehensive-use strategy, drug testing is conducted at all stages of criminal justice processing, from the pretrial stage through incarceration and release. The urgency of the drug problem and the widespread use of testing has led researchers to turn their attention to evaluating these applications.

\section{Pretrial monitoring of arrestees.} One major impetus of the comprehensive-use strategy was the desire to identify an arrestee's involvement with drugs as early as possible in criminal justice processing. Encouragement from the Federal Government led in the 1980s to the adoption of this type of dispositional drug testing in a number of cities and other jurisdictions. Monitoring arrestees before trial has become a major application of drug testing in the criminal justice system.

There is some evidence that the results of pretrial testing can predict criminal behavior or other violations (such as failure to appear in court), but that evidence is mixed. ${ }^{7}$ Whatever the evidence, there are nevertheless corollary benefits. Testing can produce informa- tion about arrestee drug-use patterns and changes in preferences for drugs. In one study of the efficacy of pretrial drug testing, the researcher concluded that the information generated can be applied to planning comprehensive testing and treatment programs.

Postconviction testing. Monitoring incarcerated offenders or people on parole, probation, or other forms of community release is the other major application of drug testing in criminal justice practice.

A specialized focus for postadjudication populations is the use of drug testing in "intensive supervision probation" (ISP). In these programs caseloads are reduced so as to enable probation officers to maintain closer surveillance of, and work more closely with, each client. ISP has become a popular mechanism for monitoring and controlling drug offenders in the community. ${ }^{8}$

As with pretrial testing, testing within the context of ISP functions as a diagnostic device as well as a possible deterrent to further drug use, at least to the extent sanctions are applied. And as with pretrial drug testing, postconviction testing may not produce the effects anticipated by program designers. Several of the most important issues raised in ISP programs are the increased demands placed on supervising officers to carry out the tests and the costs of frequent testing. If a drug violation is detected, it demands some type of response, which entails further costs. These limitations are exacerbated by the general lack of treatment available for offenders under court supervision. Nor have ISP programs yet proved successful in reducing recidivism. Rather, they have been shown to increase technical violations, which in turn increase the pressure on jails and prisons. ${ }^{9}$ 


\section{Emerging technologies}

Currently on the horizon are technological developments that represent signal advances over urinalysis. These methods may have advantages beyond cost effectiveness alone. For one thing, they offer the prospect of being less invasive and intrusive than urinalysis. Perhaps more important, these technologies may be able to detect emerging drugs of abuse. This advantage alone would enable the criminal justice system to get ahead of the curve in dealing with drug offenders by facilitating planning to allocate resources to such areas as enforcement and treatment.

Hair analysis. Several major drugs of abuse, including cocaine, heroin, and amphetamines, are rapidly excreted from the body via urine. This means the ability of urinalysis to detect them is limited. Hair analysis has been suggested as a supplement to urine testing because, by offering a longer "window" of detection, and for other reasons, it makes evasion more difficult. Because hair analysis can detect these currently popular drugs, it can help the criminal justice system to keep up with changing drug-use trends.

The scientific basis of hair analysis is the capacity of the growing hair to absorb drugs and their metabolites (the products of the body's metabolism). Once a metabolite is embedded in the hair shaft, it appears to remain there almost permanently. Although washing and manipulation can affect the concentration of drugs in hair, it does not appear that even regular hygiene can remove enough of a drug to defeat a sensitive test. As the hair shaft grows, it produces a linear record of the compounds absorbed.

Some of the same techniques used in urinalysis are also used in hair analysis. Both radioimmunoassay screen and GC/MS (chromatography) can identify the presence of cocaine and heroin (as well as other compounds) in hair.

Although hair testing is not as widely used in criminal justice practice as urinalysis, it is attracting increased interest. That is especially true where long-term drug trends are being evaluated, because of the wider window of detection. Already, hair analysis has proved effective in several applications, among them diagnosing and evaluating drug-use histories of people in voluntary treatment programs, offenders in criminal justice-based treatment programs, criminally involved youths, arrestees, and probationers in ISP programs. When introduced in court as evidence of drug use, the results of hair analysis have generally been upheld. ${ }^{10}$

Sweat patches. Since sweat is a mechanism for eliminating waste from the body, it contains drugs and drug metabolites much like urine and can be analyzed with similar technologies. But much time is needed to collect quantities sufficient for analysis. The adhesive patch is a mechanism that can overcome this problem because it is worn for an extended time before being removed and subjected to analysis.
In the past few years, the patch has undergone a number of field trials that in general have found it useful. ${ }^{11}$ Studies have shown that it has some distinct advantages, one of which is a longer window of detection than urinalysis. ${ }^{12}$ The technique is also less invasive than urinalysis, and the patches are easier than urine samples to handle, ship, and store. An obvious limitation is that it cannot detect past, long-term drug use.

Looming on the horizon are "smart patches," which conceptually are similar to the standard patch but produce results instantly. Embedded microelectronic chips create this advantage, and there may be others, among them the ability to produce information such as the date on which particular drugs were detected and the level of concentration. Smart patches appear to hold great promise but have yet to be extensively field tested.

Saliva testing. One of the most compelling aspects of saliva specimens is that they are readily available, relatively simple to collect, and do not pose problems of privacy and intrusion as does urine testing. Especially for onsite applications such as field sobriety checks, this is a distinct advantage. From a medical perspective, saliva collection is noninvasive, in contrast to the collection of plasma and blood.

Although saliva has shown its utility in detecting drugs of abuse-it has been used to identify cocaine ${ }^{13}$ and cannabinoids ${ }^{14}$ - its full potential has still to be realized. One major disadvantage is that currently the biological functions and attributes of saliva are not completely understood, and for this reason researchers have recommended using it only in conjunction with a more traditional specimen such as blood or urine. ${ }^{15}$ 


\section{Drug Testing in Criminal Justice}

Multimodal testing: the ion mobility spectrometer. The ion mobility spectrometer (IMS), which can be used in the field, is a

highly automated instrument for chemical analysis that shares some of the design and operational characteristics of the gas chromatography/mass spectrometry instrument. Like GC/MS, it depends on separation of materials moving through space to detect a unique marker or "fingerprint" uniquely associated with a known chemical compound.

The primary advantages of IMS are that it is very sensitive, has high analytic specificity, and can identify many compounds simultaneously and rapidly. It also has the potential to test many different types of specimens, including urine, hair, sweat, skin swab samples, saliva, and other materials (such as pocket lint and clothing swatches). Because it can be programmed for a variety of substances, it is relatively easy to adapt to newly emerging drugs.

Recently, probation services in several jurisdictions have been using IMS to monitor offenders or are actively exploring the technology for this purpose. It is also used by a number of Federal agencies (for example, the U.S. Customs Service, the Federal Bureau of Investigation, and the Drug Enforcement Administration) to detect drug traces on confiscated items or search locations such as the holds of ships for evidence of contraband. Although IMS appears to hold promise for drug monitoring, as with other methods now being explored, there are limitations that need to be overcome. For example, because the sensitivity of the technique may vary with the type of substance tested, it may in some instances be too sensitive and therefore unworkable. ${ }^{16}$ For this reason it may, on balance, lack any advantages over current methods. $^{17}$

\section{Policy challenges and the future of drug testing}

The evolution of drug testing in criminal justice practice represents a convergence of technological advances with several other factors: changing levels and patterns of drug use, public concern, and the political response. Each factor drives, to some extent, the shape of policies and practices adopted in jails, parole and probation offices, juvenile justice centers, and similar institutions. However, it is likely to be technology that will play a critical role in creating possibilities for policy implementation. Paradoxically, that also poses a problem, which is illustrated by the use of drug testing to supervise drug offenders in the community. For this type of use, researchers have observed that technology appears to have moved faster than some agencies' ability to effectively use the information generated. ${ }^{18}$ It appears that technological innovations on the horizon for drug testing will have the same effect- they will provide more comprehensive and precise information about drug use while offering no answers for how agencies can use the information.

Thus, although technical challenges still loom, the greater challenge will be in the realm of policy. The question is how to respond to the enhanced capability that will be made possible by forthcoming technical advances in drug testing. Looking to the future, it would seem that serious thought needs to be brought to the question: What is to be done with the technology? That question is as important as any related to the development of the technology itself.

\section{Notes}

1. "Screening" refers to the initial, rapid, first-pass test. When necessary, the substance is then submitted to a second, more exacting, "confirmatory" test using a different analytical procedure to verify the results of the first test.

2. Dole, V., W.K. Kim, and I. Eglitis, "Detection of Narcotic Drugs, Tranquilizers, Amphetamines, and Barbiturates in Urine," Journal of the American Medical Association 198 (1966):349-352; Davidow, B., N. LiPetri, and B. Quame, "A Thin-Layer Chromatographic Screening Procedure for Detecting Drug Abuse," American Journal of Clinical Pathology 50 (1968):714-819; and Heaton, A., and A. Blumberg, "Thin-Layer Chromatographic Detection of Barbiturates, 
Narcotics and Amphetamines in Urines of Patients Receiving Psychotropic Drugs," Journal of Chromatography 41 (1969):367.

3. Specificity refers to a test's exactness in identifying a chemical compound. Thus, a test that can identify a compound as an opiate (a general category of drugs) is less specific than one that can determine that a compound is heroin (a specific type of opiate).

4. Ball, J., "Research Notes: The Reliability and Validity of Interviews Obtained from 59 Narcotic Drug Addicts," American Journal of Sociology 72 (1967):650-654.

5. Page, W., et al., "Urinalysis Screened Versus Verbally Reported Drug Use: The Identification of Discrepant Groups," International Journal of the Addictions 12(4) (1977):439-450.

6. Wish, E., et al., Concordance Between Self-Reports of Drug Use and Urinalysis Test Results From Active Unapprehended Criminals, New York, New York: Narcotics and Drug Research, Inc., 1983.

7. Visher, C., "Using Drug Testing to Identify High-Risk Defendants on Release: A Study in the District of Columbia," Journal of Criminal Justice 18 (1990):321-332; Visher, C., Pretrial Drug Testing, Research in Brief, Washington, D.C.: U.S. Department of Justice, National Institute of Justice, 1992; Visher, C., "Pretrial Drug Testing: Panacea or Pandora's Box?" Annals of the American Academy of Political and Social Science 521 (May 1992):112-131; and Rhodes, W., R. Hyatt, and P. Scheiman, Predicting
Pretrial Misconduct with Drug Tests of Arrestees: Evidence from Six Sites, Research in Brief: Washington, D.C.: U.S. Department of Justice, National Institute of Justice, 1996.

8. Turner, S., J. Petersilia, and E. Deschenes, "The Implementation and Effectiveness of Drug Testing in Community Supervision: Results of an Experimental Evaluation," in Drugs and Crime: Evaluating Public Policy Initiatives, ed. D. MacKenzie and C. Uchida, Thousand Oaks, California: Sage Publications, Inc., 1994.

9. Ibid.

10. McBay, A., "Legal Challenges to Testing Hair for Drugs: A Review," International Journal of Drug Testing 1(1) (1997):34-42.

11. Baer, J., and J. Booher, "The Patch: A New Alternative to Drug Testing in the Criminal Justice System," Federal Probation 58(2) (1994):29-33.

\section{Ibid.}

13. Cone, E., and W. Weddington, "Prolonged Occurrence of Cocaine in Human Saliva and Urine after Chronic Use," Journal of Analytical Toxicology 13 (1989):65-68.

14. Gross, S., et al., "Detection of Recent Cannabis by Saliva $\Delta 9-\mathrm{THC}$ Radioimmunoassay," Journal of Analytical Toxicology 9 (1985):1-5. Cannabinoids are the psychoactive ingredients in marijuana.

15. Hold, K., et al., "Saliva as an Analytical Tool in Toxicology," International Journal of Drug Testing 1(1) (1997):1-34.
16. A test that is too sensitive is one that may detect traces of material too small to be confirmed by other processes or that under some conditions may produce positive results only because of low-level background contamination.

17. A complete treatment of IMS technology and its development can be found in Eiceman, G., and Z. Karpas, Ion Mobility Spectrometry, Boca Raton, Florida: CC Press, 1994.

18. Turner, Petersilia, and Deschenes, "The Implementation and Effectiveness of Drug Testing in Community Supervision."

\footnotetext{
Illustrations:

Page 9:

Computer screen display from the spectrometer used to confirm samples that tested positive for marijuana in preliminary screening. The upper two traces indicate the presence of the metabolite of THC, the active ingredient in marijuana. The lower two traces are an internal standard to which the findings are compared. Courtesy of Psychemedics Corporation.

Pages 9 and 11:

As part of the procedure of testing hair for illicit substances, the sample to be tested is placed in a foil strip, sealed in a tamperproof card, and then sealed again in a tamperproof plastic pouch along with the request to perform the test. Photo courtesy of Psychemedics Corporation.

Pages 9 and 14 :

Schematic diagram of a human hair follicle illustrating how drugs circulating in the blood become entrapped in the hair shaft as it grows out from the scalp. Courtesy of Psychemedics Corporation.
} 


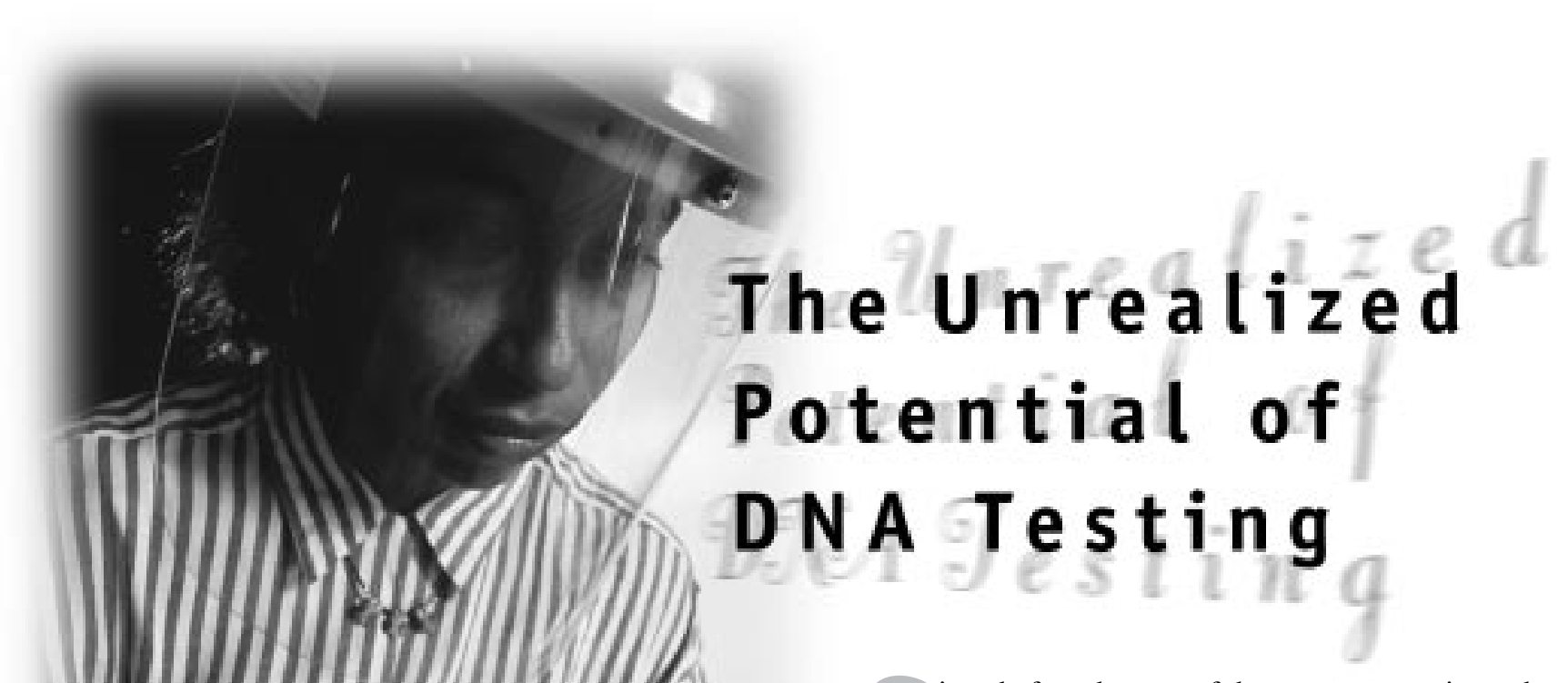




\section{An enhanced role for biological evidence}

As a result of the development of DNA testing, biological evidenceevidence commonly recovered from crime scenes in the form of blood or other body fluid-has taken on new significance. Traditional blood and saliva testing have been rendered obsolete. DNA is found in these substances and in fact in all body tissues and fluids. Because DNA testing is more sensitive than traditional serologic methods and DNA is able to withstand far harsher environmental insults, DNA testing may be successful when traditional testing is not.

Because the DNA molecule is long lived, it is likely to be detectable for many years in bones or body fluid stains from older criminal cases in which questions of identity remain unresolved. The result is that DNA testing applies to a vastly wider array of specimens than conventional testing and is much more powerful in analyzing biological evidence than any previous technology.

\section{Expanding the range of evidence}

Virtually all biological evidence found at crime scenes can be subjected to DNA testing. At most crime scenes, there are many kinds of biological evidence: not only blood and hair but also botanical, zoological, and other types of substances. ${ }^{1}$ Blood evidence was revealed in one study to be found in 60 percent of murders and in a similar percentage of assaults and batteries. Hair was found at the scene of 10 percent of robberies and 6 percent of residential burglaries. ${ }^{2}$

Multiple source. In this country DNA testing has been conducted primarily in cases of sexual assaults from vaginal swabs and semen stains. By con- trast, in England the majority of DNA database matches involve burglaries, with the evidence tested consisting of blood found at sites of forced entry. Saliva, skin cells, bone, teeth, tissue, urine, feces, and a host of other biological specimens, all of which may be found at crime scenes, are also sources of DNA. Saliva may be found in chewing gum and on cigarette butts, envelopes, and possibly drinking cups. Fingernail scrapings from an assault victim or a broken fingernail left at the scene by the perpetrator may also be useful DNA evidentiary specimens. Even hatbands and other articles of clothing may yield DNA. DNA testing of urine is becoming common to establish whether a particular individual is truly the source of the specimen in which illegal drugs have been identified.

The array of evidence that can be found at crime scenes and subjected to DNA testing suggests its unrealized potential. For despite the abundance of evidence, and despite the advantages of DNA testing, little of this evidence is recovered from crime scenes, less is submitted to crime labs, and still less is analyzed. (See "Sexual Assault Cases: Need for More DNA Processing.")

The potential for more sources. For certain kinds of DNA-laden biologic evidence, the potential has yet to be fully explored. Hair cells are an example. During a violent confrontation, hair may be transferred between the victim and the perpetrator. Traditionally, forensic scientists have been able to identify the source of this evidence on the basis of its general appearance and structural features, but rarely has it been possible to determine the source definitively. Because an individual's DNA may be detectable in his or her hair, DNA testing technology is likely to change substantially the significance and use of hair evidence.

The superficial skin cells that an individual sheds in the hundreds of thousands every hour may be prevalent at crime scenes. Their presence raises the possibility of subjecting such trace biological material to DNA testing.

Recently researchers have reported that DNA can be recovered from fingerprints, which are therefore another possible source of trace specimens that may be valuable as evidence. $^{3}$

\section{Back to the future}

The longevity of the DNA molecule means its power extends not just to the present and future but also to the past. Specimens that in many cases are years or even decades old — dating to the time when DNA testing technology was not yet available - can be tested, resulting in overturned convictions and release of the innocent.

The exoneration of Kirk Bloodsworth is an example of how the past was revisited with DNA evidence. In this case a Baltimore court, using an anonymous tip, identification from a police artist's sketch, eyewitness statements, and other evidence, found $\mathrm{Mr}$. Bloodsworth guilty of sexually assaulting and murdering a young girl. Later he was retried and again found guilty. But in 1993, more than 8 years 


\section{SEXUAL ASSAULT CASES: NEED FOR MORE DNA PROCESSING'}

Case processing of rapes could be improved if, in more instances, the DN A evidence were submitted to laboratories and tested. C urrently, in only a relatively small proportion of all rape victimizations is DN A recovered and tested. For DN A databasing of people convicted of sexual assaults, the situation is similar: Samples a re not collected, and many of those that a re collected are not tested.

$A$ recent $F B I$ survey revealed that of all rapes, less than half were solved by the police and less than 10 percent were sent to crime laboratories. And because crime laboratories are not able to work all cases submitted, in only 6 percent of the 250,000 rape cases was the recovered DNA tested, leaving a backlog of several thousand cases awaiting processing (see below).

O $\mathrm{f}$ all convictions for sexual assaults (whether felonies or misdemeanors) from which DN A collection is legislatively mandated for database matching purposes, DN A was obtained from less than half the individuals, and in less than one-third were the samples DN A typed (see below ). This proportion is an improvement over the past; however, of the overall, cumulative number of DN A samples collected $(452,000$ in the 35 States participating in CODIS), only 20 percent have been typed. Exacerbating this limited databasing is that the mismatch between DN A typing systems prevents comparison searches; for example, most casew ork is now performed using PC R analysis, while RFIP typing is performed on the vast majority of collected DN A database samples.

Fortunately, the situation is improving for rape cases: These low DN A utilization rates represent a substantial increase in DN A testing over the previous year (19 percent for DN A typing casework and 30 percent for DN A data basing). How ever, for nonsexual a ssa ult crimes, DN A testing is limited or in some cases even nonexistent

$\begin{array}{lrr}\text { Rapes } & \text { Number } & \text { \% } \\ \text { Victimizations } & 250,000 & (100) \\ \text { Investigated by Police } & 100,000 & 40 \\ \text { DN A Submitted to Crime } & 22,000 * & 9 \\ \text { Labs } & & \\ \text { DN A Processed by Labs } & 16,000 & 6 \\ \text { Backlog in Labs } & 6,000 & -\end{array}$

* 0 f the remaining 78,000 rape cases in which DN A was not submitted, 48,000 remained unsolved. The rest $(30,000)$ were solved without the use of DN A evidence.

\section{DNA Databasing (Sexual Assaults)}

Convictions

DN A Collected

DN A Typed

DN A N ot Typed

\begin{tabular}{rr} 
Number & $\frac{\%}{\text { \% }}$ \\
\hline 165,000 & $(100)$ \\
80,000 & 48 \\
45,000 & 27 \\
35,000 & 73
\end{tabular}

\section{Note}

1. These da ta were presented by Stephen N iezgoda, C O DIS Program M anager, FBI, at the A merican Society of C rime Labora tory Directors' 25 th Annual Symposium on C rime Laboratory Development, San Antonio, Texas, September 18, 1997. Data on number of rapes are from the Burea u of Justice Statistics N a tiona I C rime Victimization Survey; the other da ta are from the FBI's forthcoming 1997 C 0 DIS Survey of DN A Laboratories. The survey used information from the States for the period January 1996 through June 1997, and projected data to the end of fiscal year 1998 . 
after his arrest, prosecutors compared DNA evidence from the victim's clothing to Mr. Bloodsworth's and found the two did not match. He was subsequently released and then pardoned.

As of this writing, dozens of other inmates have been released on the basis of similar evidence. A number of examples of cases in which DNA testing furnished new evidence that resulted in the release of people wrongly convicted have been published. ${ }^{4}$

\section{Limitations to overcome}

The fact that much forensic biologic evidence remains unrecovered and unanalyzed is only one obstacle to realizing the full potential of DNA testing. Other limitations stem from lack of sufficient laboratory funding, timeconsuming testing methods, inability to test in the field, and the challenges of automating DNA evidence databases. These problems are serious, but new developments suggest they can be overcome.

Laboratory testing-funding low, processing slow. For the full potential of DNA evidence to be realized, forensic laboratories must have resources sufficient to test the evidence submitted to them. But laboratories are notoriously underfunded, and many already face heavy backlogs of work. Law enforcement agencies are often forced to distribute scarce resources among a range of pressing needs, and the labs vie for funding in this highly competitive environment.

Exacerbating this difficulty, and explaining why limited testing is done, are the slow, costly testing methods currently used. Because they are so time consuming, crime laboratories must prioritize cases to be processed and specimens to test. It is not possible, given the deadlines imposed by the needs of the courts, to analyze all potential evidentiary specimens submitted. Thanks to the development of new methods of analysis, however, crime laboratories' ability to process DNA evidence within a reasonable time is expected to improve substantially within the next few years. (See "In the Pipeline: New and Improved Testing Technologies.”)

Field testing-being tested. Investigatory leads often grow cold within a very short time after a crime is committed. Suspects vanish, witnesses disperse, and potential physical evidence may persist for only a limited time or may be disturbed in some way, even by normal activities. Although faster processing in the laboratory is important, in many cases the ability to secure critical information by field testing at the crime scene might significantly enhance the likelihood of a successful resolution.

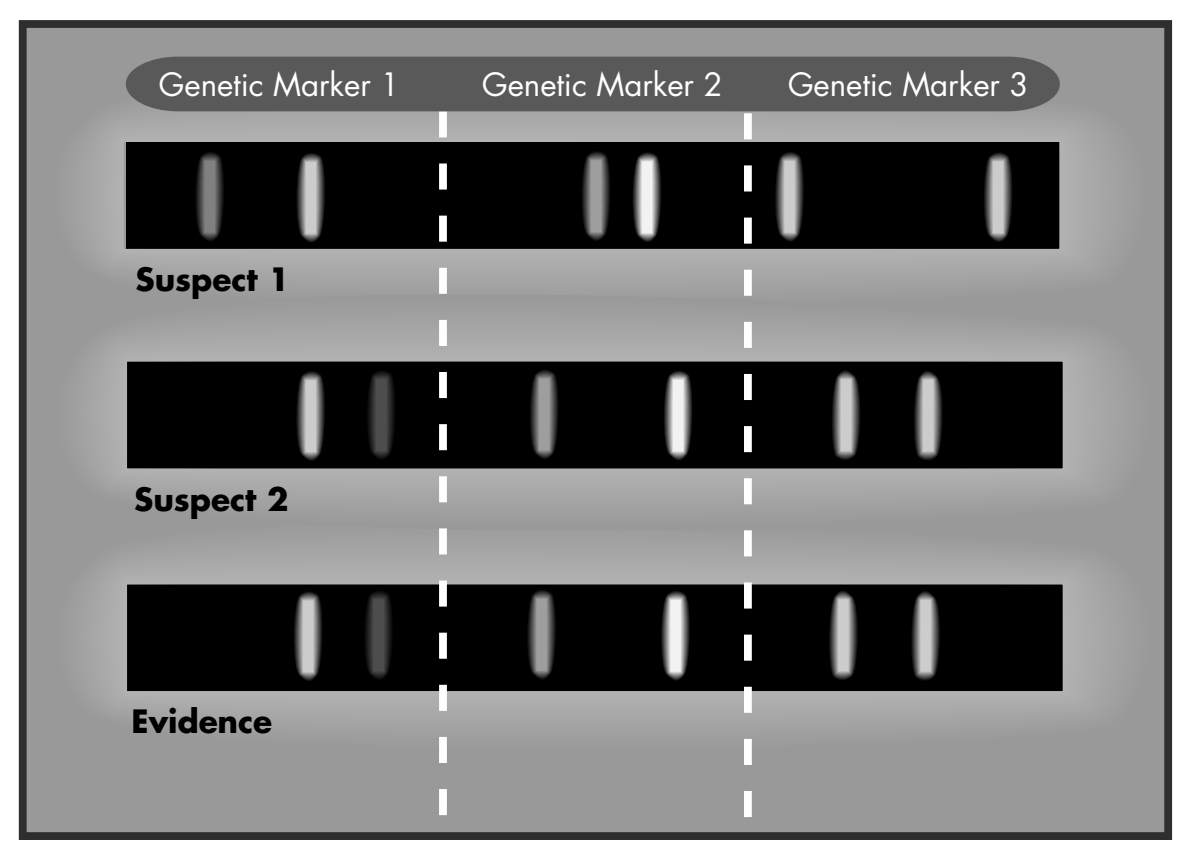

Method of Matching DNA Patterns Using STRs

STR (short tandem repeat) genetic markers run simultaneously on known and questioned DNA samples. Each person will have a maximum of two traits for each marker examined. The analyst identifies the traits for each of the three markers and determines whether the traits for the evidence match the traits from the samples of the suspects' DNA. In this case, the pattern of the evidential specimen matches that of suspect 2. 
$M$ ore rapid processing of DN A evidence should be possible within the next few years as a result of improvements in testing technology now under way.

The first widespread use of DN A tests in the criminal justice community involved RFLP (restriction fragment length polymorphism) analysis, which was informationally rich but to ok a long time- about 6 weeks. Recent nonradioisotopic methods have considerably reduced the turnaround time of RFIP. $\mathrm{N}$ onetheless, it is anticipated that RFIP testing will eventually be supplanted by PC R (polymerase chain reaction)-based technology.

It takes only days to perform PC R-based dot/ blots and, more recenty, STRs (short tandem repeats). M o reover, current STR marker sets produce as much information as RFIP tests and can be used with extremely small and degraded DN A specimens. STRs have only recently become commercially avail- able, but already they are anticipated to supersede less informative dot/ blot systems.

Developments that will further automate DN A a nalysis are being developed as an outgrow th of the Human $G$ enome Project ${ }^{1}$ These include robots, microchipbased instrumentation, and mass spectrometry. The run time of such instruments may be only minutes or even seconds. Performance of 100 STR analyses within an hour using an automated mass spectrometer has been demonstrated in a research setting.

Support for development of microchip and mass spectrometric work in forensic DN A testing is being provided by the $\mathrm{N}$ ational Institute of Justice. Today the resulting systems are in operation in only a few research centers, but a re likely to become commercially a vailable in the next few years.

1. The Human $\mathrm{G}$ enome Project (HPG) is an international, 15 -year effort, begun in 1990 , to discover all the genes in the human body's DN A and determine the complete sequence of DN A. A major focus of HPG is development of a uto mated technology for the sequencing process.

firmatory testing in the controlled environment of the laboratory should continue to be conducted to ensure absolute confidence in the results. The role of preliminary analysis in the field would be to eliminate certain individuals as suspects, arguably always a more important role for DNA evidence than incrimination. ${ }^{5}$

Steps are now under way to realize the potential of field testing DNA evidence. Recently, a truly portable microchip-based prototype field-testing instrument has been developed. ${ }^{6}$ The instrument, which produces findings within 30 minutes, is currently being upgraded and made available commercially. The National Institute of Justice is sponsoring the development of other types of portable field instruments.

DNA databases-in their infancy. Without computerized searching and without suspects, evidentiary testing, no matter how powerful, can do little more than link crimes together and is of little use in solving them. In the same way that fingerprint registries and then automated fingerprint identification systems each dramatically enhanced the utility of fingerprint evidence, the development of DNA databases and networks can substantially augment DNA profiling.

Information in the database, which consists of DNA test results from individuals convicted of certain categories of crime and DNA from the scenes of unsolved crimes, can be compared to results of evidence obtained at recent crime scenes to find associations. This creates DNA databasing's greatest advantage: its use as an investigative tool in cases where there are no suspects. However, jurisdictions must process suspectless cases to produce "cold hits" (matches lacking previous leads). Databanking in the United States is still limited, but as with testing technologies, it continues to evolve.

\section{The status of databanking}

In the U.S. Today almost all States have legislation related to DNA databanking, most of it focusing on collecting and testing DNA from individuals convicted of sexual assaults and often homicides. In some cases the legislation requires collection from all convicted felons. Although DNA databanking was proposed almost 10 years ago, and although databanking has been almost universally adopted at the State level, the concept of its development in this country is still rudimentary. 
The limitations are partly due to the definition of offender categories in the legislation. For example, rapists who plead to a lesser offense not covered by a particular State databanking law are therefore not subject to it. Similarly, in some States DNA collection laws are inapplicable to juveniles involved in the criminal justice system. In other instances DNA is not collected until an offender is released, instead of at intake, making it impossible to match the offender's DNA to that in a case opened during incarceration. Other problems stem from lack of funding and the incompatibility of the States' genetic testing systems. Of the 47 States that have passed legislation, the program is operational in only 36 , and of that number most programs are severely backlogged.

In the U.K. Compared to the United States, the United Kingdom has moved far more aggressively to establish a national DNA criminal database.

Specimens are collected from a wider range of offense categories than the sexual assault category targeted by most State programs in the United States. The number of DNA profiles entered thus far in the U.K. is now nearly $200,000{ }^{7}$ with an expected increase to more than 5 million specimens in the next decade.

conviction. In testing technology, the U.K. has switched completely to automated STR, which is able to discriminate among every man, woman, and child in the country. By contrast, most databasing in the United States uses RFLP results. (For an explanation of RFLP and related terms, see "A Primer of DNA Testing Technology."') Laboratory processes in the U.K. have been streamlined and automated and

The U.K. has taken other steps to increase the utility of its database. Specimens are taken upon arrest rather than, as in virtually all the States in the United States, on

\section{METHOD OF MATCHING DNA PATTERNS USING RFLP}

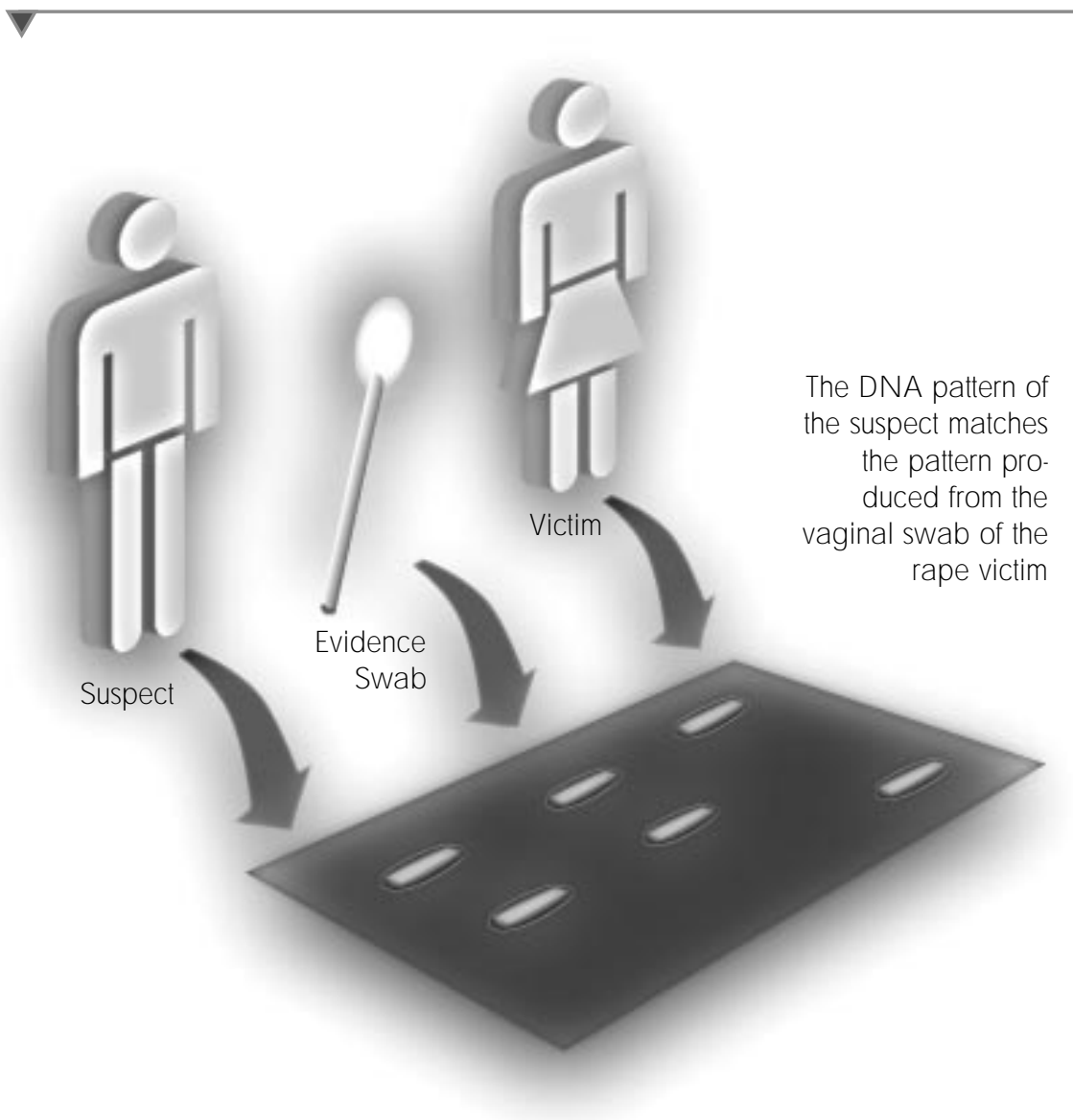

The DN A pattern of suspect matches the pattern produced from the ginal swab of the rape victim 


\section{A PRIMER OF DNA TESTING TECHNOLOGY}

DN A is the chemical deoxyribonucleic acid, which stores the genetic code of the human body - the hereditary blueprint imparted to us by our parents. DN A is useful in forensics because it is present in all cells, is the same throughout the body, and does not change in the course of a person's life. Perhaps most important, for each individual (except identical twins) the DN A sequence (the order of the DN A building blocks) is different, making each person's DN A unique.

\section{RFLP}

The first type of forensic DN A test to be widely used by crime laboratories was restriction fragment length polymorphism (RFIP), based on the variation among individuals in the length of the DN A fragments. In the RFIP method, DN A is extracted and cut by an enzyme into restriction fragments, which a re suspended in a gel, divided up by size, and transferred from the gel by blotting onto a membrane. In order for the examiner to see the fragments, they are identified by radioactively labeled probes, and the membrane is placed over an x-ray film. The radiation from the probe exposes the film and produces a picture of the DN A fragments, called an "autora diogram."

A match is made when the patterns produced by DN A from an evidence stain and those from a suspect's sample DN A are found to be the same. An estimate of the statistical probability that this evidence is from the suspect rather than someone selected at random is then calculated. RFIP is pow erful but is relatively insensitive, cannot be applied to degraded specimens, and is tedious and time consuming, taking about 6 weeks. More recently, to avoid the precautions needed to handle radioactive samples and to speed processing time, other labeling systems have been adopted, including chemiluminescent and fluorescent methods.

\section{PCR}

If a forensic sample is to o small for RFIP testing or if the DN $A$ is degraded, polymerase chain reaction (PC R) testing may be used to obtain a DN A typing result. PC R is a method of preparing samples in which the targeted DN A is copied many times (amplified). Two DN A molecules are produced from the original molecule; the procedure is repeated many times with a doubling of DN A fragments every time. Eventually millions of copies of a DN A sequence are produced. Although $P C R$ is very sensitive, permitting analysis of as little as a single copy of DN A, this sensitivity also makes the sample susceptible to contamination. N IJ has provided support for the development of PC R as well as RFLP testing standards. ${ }^{1}$

\section{Reverse dot/blots}

The original application of PC R to DN A testing involved what is called dot blot analysis. In a given region of $D N A$, there is a finite number of possible sequences ("alleles") between individuals, and a probe can be developed to determine the alleles present. In reverse dot/ blot analysis, used by some forensic laboratories, amplified DN A binds to probes attached to a membrane. M embrane strips produce a blue dot in the presence of the bound, amplified DN A. Although these tests may be useful in many circumstances, their discriminatory pow er is low compared to other DN A typing methods, and one specimen may be contaminated with DN A from another person.

\section{STRs}

It is possible to amplify regions of the DN A molecule that show variation in DN A fragment length between individuals rather than using the RFLP method of isolating and cutting out these regions. The forensic community has found that smaller sets of fragments, called short tandem repeats (STRS), a re preferable for several technical reasons. The technique of using STRs is easier and faster than RFL, and the analysis can be performed with a number of different auto mated and semiautomated methods, such as capillary electrophoresis, ${ }^{2}$ which is particularly rapid and highly a uto mated.

\section{Notes}

1. In cooperation with the $O$ ffice of Law Enforcement Standards of the $\mathrm{N}$ ational Institute of Standards and Technology, $\mathrm{N}$ IJ has initiated development of standards for the RFLP and PC R testing methods.

2. $\mathrm{N}$ IJ provided support for applying capillary electrophoresis to forensics. 
The CODIS system (COmbined DNA Index System) is a national investigative support database. Developed by the FBI, it is used in the national (NDIS), State (SDIS), and local (LDIS) DNA Index System networks to link the typing results from unsolved crime cases in multiple jurisdictions or to those convicted of offenses specified in the DNA databanking laws passed in 47 States. By alerting investigators to similarities among unsolved crimes, CODIS can aid in apprehending perpetrators who commit a series of crimes and in this way prevent other offenses by the same person. The 77 laboratories in the 36 States participating in CODIS have produced 126 case-to-case "hits" and 76 case-to-offender "hits."

For CODIS to work efficiently, all forensic laboratories must use reliable and compatible DNA test systems so that data can be compared. To that end the Violent Crime Control and Law Enforcement Act of 1994 promotes uniform standards for forensic DNA testing and provides Federal support to State and local law enforcement agencies to improve their DNA testing capabilities so they can participate in CODIS. ${ }^{8}$ Also, to establish minimal compatibility among laboratories, the FBI has promulgated a core set of RFLP genetic loci (specific places in DNA) and will promulgate a core set of STR loci.

\section{On the horizon}

Improved testing technologies are ensuring more efficient and effective DNA evidence processing, advances in technology and databanking promise to widen the use of DNA evidence as an investigational tool, and new sources of biologic evidence are being explored. Nevertheless, we are still far from full realization of the potential of DNA testing. As laboratories improve their ability to process DNA evidence quickly, and as the courts' expectations of the use of DNA test results increases, there will be greater emphasis on initial collection of evidence at the crime scene.

Initial collection of evidence is a key link in the chain of events leading to successful testing, but it is also a vulnerable link. Currently the groundwork is being prepared to strengthen specimen collection and preservation, with more structured crime-scene teams and more formalized evidence collection procedures being established in many jurisdictions. The aim of these teams is to ensure that all potential evidence is recovered and properly preserved for testing, and especially to minimize the possibility of contamination.

Today much evidence is not retrieved, submitted to the lab, or analyzed. Crime labs are neither adequately funded nor fully supported. Database registries are not comprehensive and not fully utilized. People still get away with murder. But if the potential of DNA testing can be fully realized, their chances are likely to be greatly reduced.

\section{Notes}

1. Parker, B., and J. Peterson, "Physical Evidence Utilization," in The Administration of Criminal Justice, Technology III, ed. S.I. Cohn and W.B. McMahon, Chicago, Illinois: ITT Research Institute, 1970. This is the only comprehensive study of physical evidence from crime scenes.

\section{Ibid.}

3. Van Oorschot, R.A.H., and M.K. Jones, "DNA Fingerprints From Fingerprints," Nature 387 (1997):767.
4. Conners, Edward, et al., Convicted by Juries, Exonerated by Science: Case Studies in the Use of DNA Evidence to Establish Innocence After Trial, Research Report, Washington, D.C., U.S. Department of Justice, National Institute of Justice, June 1996, NCJ 161258.

5. According to statistics from the FBI, the States, and crime laboratories from other countries, DNA testing has excluded the named subject as the source of the suspect DNA in about one-third of the cases received for testing.

6. Belgrader, P.J., et al., "Rapid PCR Identity Testing Using a BatteryPowered Miniature Thermal Cycler," Journal of Forensic Sciences (in press); and Ibrahim, M.S., et al., "Real-Time Microchip PCR for Detecting Single Base Differences in Viral and Human DNA," submitted to Analytical Chemistry.

7. Personal communication with Lyn Fereday of the United Kingdom's Forensic Science Service, Reading, England, July 15, 1997.

8. The aim of the DNA Identification Act of 1994, Title XXI of the Violent Crime Control and Law Enforcement Act of 1994 (the Crime Act), is to increase the capabilities and capacity of State and local forensic laboratories to conduct DNA testing. In the first year, NIJ awarded $\$ 8.75$ million to 31 States, $\$ 8$ million of which was provided from the FBI.

\footnotetext{
Photo:

Page 16:

A research scientist looks through a light box at DNA fragments suspended in a gel to ascertain the quality and quantity of the material to prepare for testing using the RFLP method.

Photo courtesy of the National Institute of Standards and Technology.
} 


\section{Looking Backward to Look Forward: The 1967 Crime Commission Report}

in Retrospect

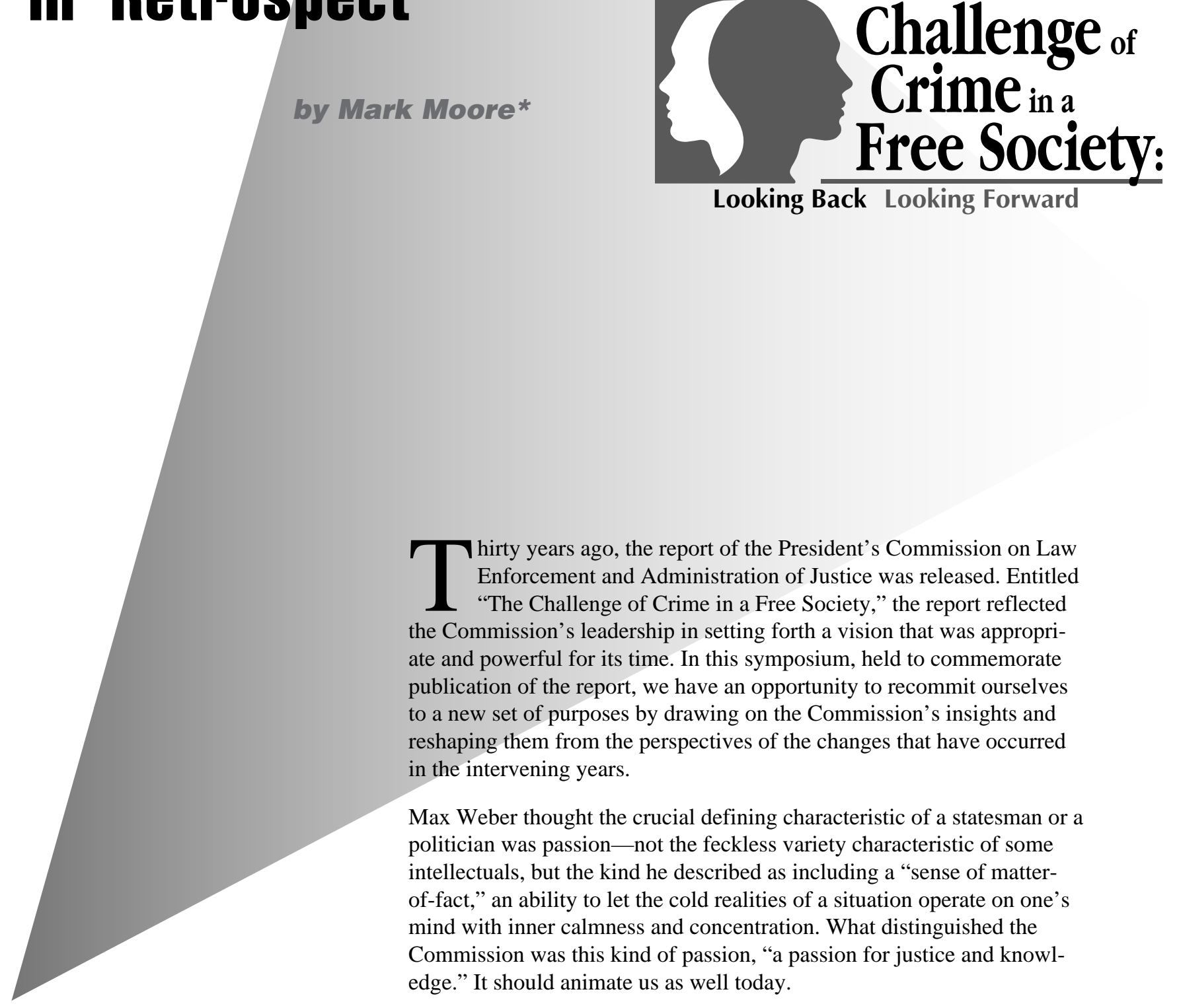

The

Max Weber thought the crucial defining characteristic of a statesman or a politician was passion-not the feckless variety characteristic of some intellectuals, but the kind he described as including a "sense of matterof-fact," an ability to let the cold realities of a situation operate on one's mind with inner calmness and concentration. What distinguished the Commission was this kind of passion, "a passion for justice and knowledge.” It should animate us as well today.

\footnotetext{
*Mark H. Moore, Ph.D., is Guggenheim Professor of Criminal Justice Policy and Management at Harvard University's Kennedy School of Government. This article is an abridgment of the address he presented at the closing of the symposium on the 30th anniversary of the President's Commission on Law Enforcement and Administration of Justice, sponsored by the Office of Justice Programs and the Office of Community Oriented Policing Services, U.S. Department of Justice. The address was a synthesis of the symposium proceedings.
} 


\section{The Commission's vision: better criminal justice in the context of a commitment to social justice}

The Crime Commission delivered two major messages. The first was an operational theory of what society would have to do to produce an effective and decent criminal justice system. The second was a larger idea about what society would have to do to deal with crime. The two are not the same. The Commission judged that the criminal justice system had to be constructed, reformed, and developed in ways that would enable it to deliver justice reliably and well. But in their view, this was not the only requirement for controlling crime. To meet the "challenge of crime in a free society," we had to work at producing social justice as well as producing criminal justice.

Aside from this substantive vision of the Commission was the managerial or implementation vision of how the processes and institutions of the criminal justice system needed to be developed. These serve either to implement whatever strategy is decided upon, or are a way of developing and adopting a new idea if the old idea turns out to be inappropriate. I want to first discuss the Commission's vision of the operational theory of crime control through the justice system, and second to discuss the managerial or process theory of what is needed to reform the criminal justice system if not the social justice system.

Controlling crime, preserving liberty, ensuring fairness. The Commission understood there were two important values to be preserved in criminal justice system operations that might be in opposition to each other. On the one hand is the goal of controlling crime, which could be achieved, perhaps, if we were willing to expend a great deal of State authority and reduce individual freedom. But the Commission was dead set against that because they thought another important societal goal should be to minimize the use of State authority. The Commission conceptualized the value question as: How could we reduce crime while preserving freedom? They understood that the goal of the system was to control crime with justice, not simply control crime. Freedom and justice also meant a sustained effort to expunge race and class bias from criminal justice system operations.
Because the Commission's goal was to see that authority was invoked only when justified, the operations of the criminal justice system had to be reformed and reshaped. That meant being willing to take a loss in crime control effectiveness. They then, I think, hoped to replace some of the potentially lost effectiveness through greater efficiency in the operations of the criminal justice system, through the application of scientific management, and through more effective cooperation among the various elements of the system.
“THE CHALLENGE OF CRIME IN A FREE SOCIETY" - 30 YEARS LATER

\section{V}

Impelled by the high level of public concern about crime in the 1960s, President Lyndon Baines Johnson ordered the establishment of the President's Commission on Law Enforcement and Administration of Justice, whose mission was to examine "every facet of crime and law enforcement in America." The results of that examination, which covered the nature and amount of crime and crime trends in America, were published in 1967 as "The Challenge of Crime in a Free Society." The Commission's work laid the foundation for the current Federal role in assisting State and local law enforcement and justice administration. The Justice Department's Office of Justice Programs evolved from predecessor organizations created as a result of the Commission.

In a retrospective held in June 1997, prominent criminologists; professionals and practitioners from law enforcement, the courts, and corrections; Federal and State officials; and members of the Commission staff convened in a symposium to commemorate the landmark report. They assessed the reach of change that has occurred in the intervening years, focusing on the outcome of the Commission's recommendations. The symposium, whose theme was "looking backward, looking forward," was sponsored by the Office of Justice Programs (OJP), its constituent bureaus, and the Justice Department's Office of Community Oriented Policing Services. Participants examined changes in the nature of crime and the criminal justice system, in the use of research and statistics, and in the societal response to crime and the criminal justice system.

A publication based on the symposium papers, including the full address by Mark Moore, who synthesized the proceedings, is now being prepared by OJP. 


\section{Looking BackWard to Look ForWard}

James Vorenberg (center) was Executive Director of the Crime Commission from 1965 to 1967. He is now Roscoe Pound Professor of Law at Harvard. John McCausland (left), one of his assistants on the Commission, became an attorney and is now an Episcopal priest, serving parishes in New Hampshire. Sheila Ann Mulvihill, also a member of the Commission staff, is now an editor for the National Academy of Sciences and other organizations.
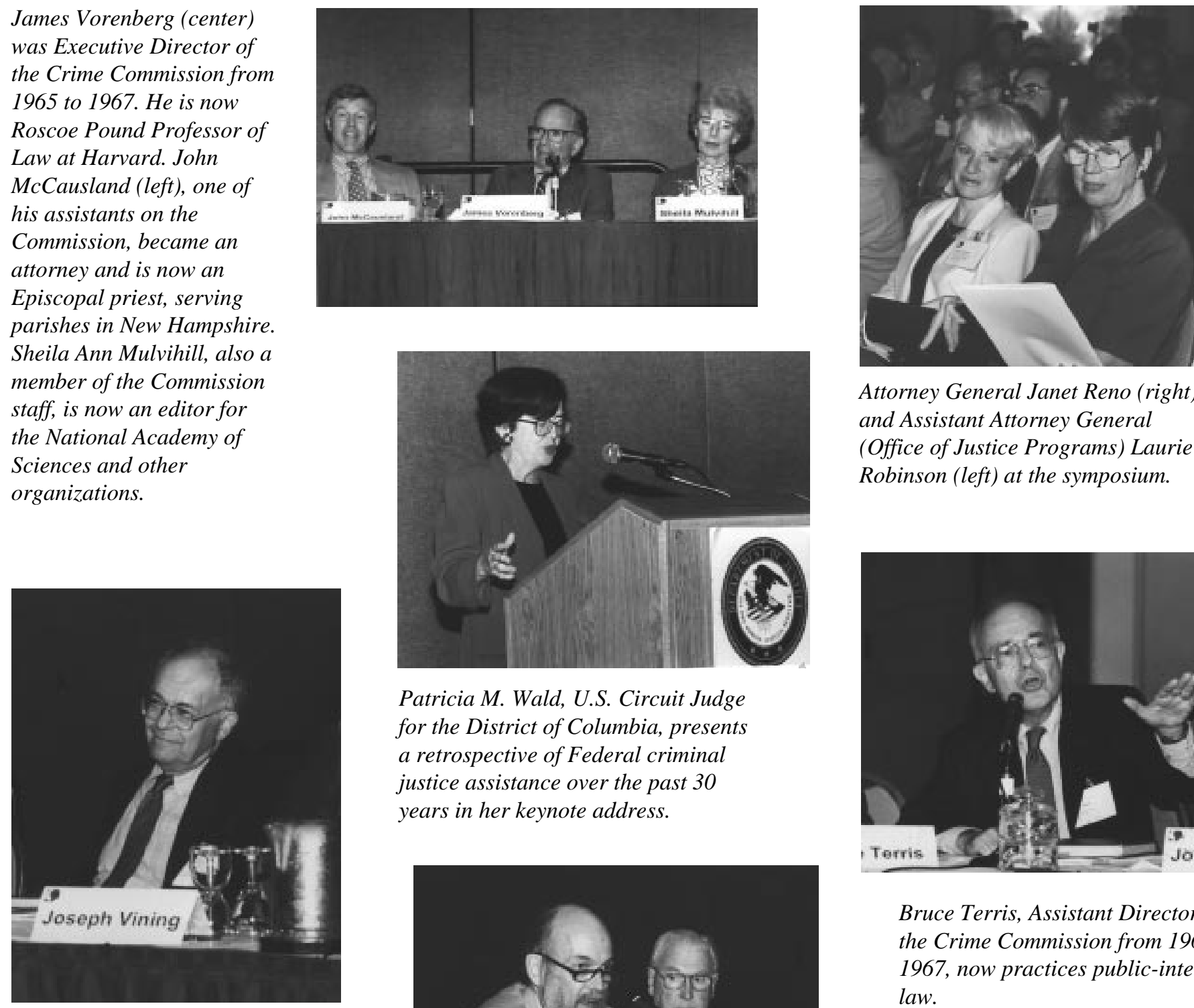

Attorney General Janet Reno (right) and Assistant Attorney General (Office of Justice Programs) Laurie Robinson (left) at the symposium.

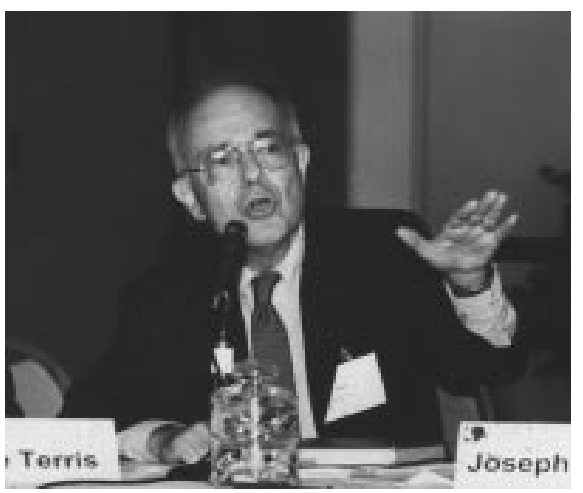

Patricia M. Wald, U.S. Circuit Judge for the District of Columbia, presents a retrospective of Federal criminal justice assistance over the past 30 years in her keynote address.

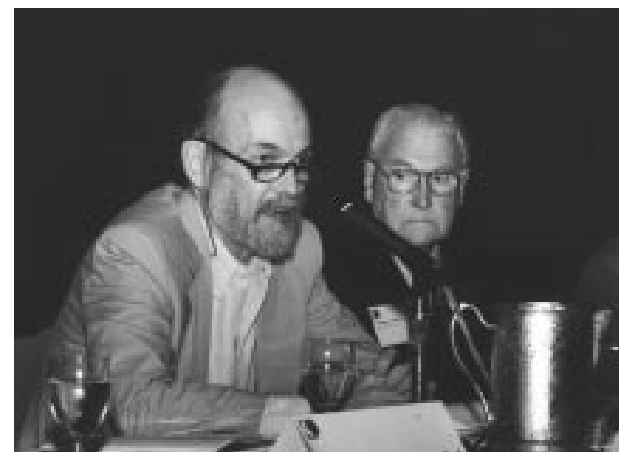

Bruce Terris, Assistant Director of the Crime Commission from 1965 to 1967, now practices public-interest law.

David Burnham (left), Assistant Director of the Commission in 1965, is now a professor at Syracuse University and codirector of the Transactional Records Access Clearinghouse; Thomas Cahill (right) served on the Commission from 1965 to 1967 and is now retired from the San Francisco Police Department, remaining active as a past president of the International Association of Chiefs of Police.

\section{A Gallery of Symposium Participants}

Photos by Twin Lens Photo 
The complementary role of social justice. In its report, the Commission went on to say that although reform of the criminal justice system could produce criminal justice, it would not necessarily control crime. The real solution to the crime problem lay in the creation of social justice. The Commission discussed the importance of providing education, recreation, jobs, and strong families for kids as the way of controlling crime. Today, we could go further in thinking about social justice, recognizing the needs of adults as well as children. That might mean thinking about what to do with adjudicated offenders, and it might also mean a special obligation to concentrate on reducing racial disparities and the perception and reality of racial discrimination. In short, in the Commission's view, it was important to do social justice as well as criminal justice not only because social justice is a good in itself, but also because it would strengthen the performance of the criminal justice system.

In sum, the substantive vision of the Commission was to offer the Nation a way to deal with its crime problem in a just and fair way that would preserve liberty and realize the promise of democracy. In that vision, we had to repair the criminal justice system and make it operate justly and fairly, but we also had to repair the social system through a social justice policy that would create the conditions under which the criminal justice system could be both effective and fair.

\section{A contemporary critique of the Crime Commission vision}

Although in many respects the Commission's vision has stood the test of time, from today's perspective it may perhaps be a too narrow or austere view of criminal justice.
Criminal justice and just relationships. What we might want to consider is that the institutions of the criminal justice system ought to be trying to produce justice, not simply crime control within a context of restricting civil liberties. That would mean, among other things, paying attention to the rights of the defendant, and this was the part of justice on which the Crime Commission focused our attention. It would also mean paying attention to the rights - and the interests, and the feelings — of victims.

But there's an even more ambitious vision of justice. The idea of justice isn't simply that we balance the defendant's rights against the victim's rights in deciding what is a proportionate sentence. It is, instead, that the courts do the work of restructuring relationships that have come apart. The purpose of the many specialized courts-drug courts, family courts, juvenile courts, the restorative justice processes-is to construct just relationships. The aim is to do so not only among strangers (offenders and victims), but also among more intimate groups-husbands and wives, neighborhood merchants and the kids who victimized them, parents who become estranged from their kids- to construct a whole set of social relationships that ought to be guided and shaped by justice and mutual responsibility and even love.

Government can't create love, but it can create the occasions in which love-or tolerance, or obligation, or duty—might be rediscovered. It may be that this is the important idea of justice that we would try to build into a justice system—a "thicker," more substantial concept of justice than the guarantee of due process rights of victims and offenders.

It's easiest to imagine that the relationship the criminal justice system is trying to construct is best described in due process terms when we're talking about relationships between offenders and victims who don't know one another. But I would argue that even this is too abstract and attenuated a view of these relationships, let alone of relationships between victims and offenders who are intimates. We need to be reminded that all offenders-or most of them-come back to the community. In other words, our relationship with them will be ongoing.

People with the type of passion Weber recommended might recognize this, but it flies in the face of two common fantasies about the criminal justice system, which I'll call the Right Fantasy and the Left Fantasy. In the Right Fantasy, when people commit crime, we can end our relationship with them either by locking them up and throwing away the key or by executing them. In the Left Fantasy, when people commit crime, it gives us an opportunity to supply them with enough services to turn them into the person they always wanted to be.

In some sense, both those fantasies are deeply flawed. The reality is that we are going to be locked into a long-term relationship with offenders. So we might want to ask, "What kind of a relationship do we want to have?" That is a very different way of asking the question, "What are we trying to do with criminal justice dispositions?" We are asking what would be a just relationship for us to have, as well as what relationship would achieve some practical goals in controlling crime.

Partnerships across boundaries. The Commission held the view that it was important for each institution to get outside its boundaries and see itself as interacting with other institutions in broader systems. That was an important idea. But the interactions that the Commission highlighted were those of the agencies within the criminal justice system. Thus, police had to inter- 
act with prosecutors, prosecutors had to interact with courts, courts had to interact with correctional institutions, and so forth.

The key relationships missing from the Commission's view were those with other governmental unitschild welfare, parks and recreation, the public education system-and those with the communities that would be necessary to animate and give weight and power to an emerging conception of a justice system that wanted to produce "thick" justice rather than the austere sort.

In working with victims and offenders, and particularly with children, we need to foster naturally occurring systems of support outside the justice system. For example, in criminal justice institutions like drug courts, we need to bring in parents, coworkers, and supervisors and engage them in the process of controlling the behavior of the offender and helping him or her stay off drugs. We are reaching into informal systems of control, support, and assistance, using the apparatus of the criminal justice system to mobilize and shape that particular kind of control.

The criminal justice system as a support to social justice. My third point about the Crime Commission's substantive vision is that it did not include the idea that criminal justice system operations might support the construction of conditions that could lead to social justice. Of course, it would be easy to overestimate the extent to which the institutions of the criminal justice system could do this. But it would also be a mistake, I think, not to recognize the contribution these institutions could make.

To understand this, we need to think not only of crime as the result of social injustice, but also of crime control as a means to the end of producing social justice. Some might object to this on grounds that we would be attempting to execute social policy by creating new criminal liability and thus a new responsibility for the criminal justice system. An example is the prospect of criminalizing attacks of parents against children in the same way we have criminalized attacks of men against women in the context of domestic violence. To criminalize such acts could be perceived as wrong because it is an inappropriate use of State power or it is an imprudent use of State power. But the fact is we do not know whether it would be wrong. If it were wrong in either respect, then that might create an opportunity for the criminal justice system to support what had previously been considered an important goal of social policy: to produce safe families. In the Commission report, there was no suggestion that the criminal justice system as a whole could support and help further the goals of the social justice system beyond providing a tolerably just and effective response to those who had committed offenses.

Crime prevention. It is significant, I think, that the first chapter of the Crime Commission's report was about prevention. But what I think is quite interesting is that we have a very broad juxtaposition of different systems of prevention. According to the prevention theory associated with criminal justice operations, we can prevent crime (if not the first, at least many subsequent crimes) through deterrence, incapacitation, and rehabilitation. We might even prevent an offender's first offense if general deterrence works.

At the other extreme is a social justice theory of prevention. It holds that if we extended great opportunities to both children and adults to live profitably and well and if we lived up to the promise of equality of opportunity, fewer people would wish to become offenders, would choose to become offenders, or would feel motivated to become offenders. So we have criminal justice prevention on the one hand (reactive, with extensive use of State authority) and the social justice theory of prevention on the other (anticipatory, hopeful, accepting of our broader responsibilities to society at large, holding open the possibility of realizing a society we'd all like to be part of). Those are the two ideas of prevention presented in the Commission report.

How much space is there between those different ideas of prevention and how much of that space have we explored at this stage to find effective crime prevention techniques? By way of an answer, let me start from the Right end, with the "spare" deterrence-incapacitation and rehabilitation - of professional criminal justice agencies. To find another kind of prevention, you could take one step over and discover that a great deal of what is celebrated as important preventive techniques I would describe as "thick" deterrence. It functions the way mentors function. You behave when your mentor is sitting next to you, partly because he or she is sitting next to you. You may have impulses to break loose, but with your mentor next to you, you know where your duty lies. 
There's a concept of support in that closeness, but there's also control.

Let me explain how "thick" deterrence might be applied to handling persistent minor offenders. They are a very difficult problem in the criminal justice system; their persistence makes it hard to ignore the fact that they're leaving behind a string of victims. On the other hand, their offenses aren't very serious, so it doesn't seem appropriate to sever our relationship to them by either life imprisonment or execution. I recall watching James Vorenberg, a member of the Crime Commission (who is here today), on television shortly after publication of the Commission report, talking about this type of offender. He said, "There are just some people who need a leash." That is the picture of "thick" deterrence: prevention different from probation and also different from incapacitation.

Another idea of prevention, much discussed recently, is "situational crime prevention": reducing the opportunities to commit offenses. Some portion of that idea lies in making less property available to be stolen. But another part is trying to reduce the number of occasions in which people will be provoked into committing crime. Once again, we begin thinking about relationships - as potentially criminogenic and needing to be fixed as a way to block the opportunity for future offending. Those relationships are in domestic violence, child abuse and neglect, crimes committed among gangs, and even hate crimes. All acquire their meaning and motivation through relationships, not through the acquisition of property. If the courts and other parts of the criminal justice system are in the business of reconstructing relationships, they may be able to reduce these crimes.

Notice what I'm doing is edging over to the categories of prevention that eventually reach the "root causes of crime" approach to prevention. The one step remaining before I get there is the concept of prevention most popular in our symposium discussion: as an interruption of the trajectories of children headed toward future criminal offending. A number of researchers have demonstrated the possibility of intervening early in children's development to deflect them from careers of criminal offending.

In sum, the point I wish to make is that there is a general concept of prevention, widely and enthusiastically embraced for a long time. In order for that concept to become operational, we have to have a much more differentiated and clear picture of prevention; more specifically, which notions of prevention I've talked about are included in the general idea. In the recent crime control debate, one of the sadder aspects is the loss of an argument about crime prevention. A truly distinctive aspect of the Clinton administration's approach to crime was its willingness to emphasize prevention of a particular type and to include it in Federal crime legislation. The constraints subsequently placed on this idea have been disappointing. The argument that the Crime Commission set us up to be able to make was recently lost, and I think we need to reclaim some of that terrain.

\section{Institutions and processes}

Some of the Crime Commission's views of criminal justice processes and institutions might also be altered in our contemporary view.

Effective policymaking. In our symposium discussions, we spent a lot of time talking about effective policymaking. We espoused an idea of policymaking guided by data and knowledge rather than ideology and base passion-guided by a sort of
Weberian approach to passion. And yet today in a panel of policymakers, the dominant theme was the importance of righteous anger, "craziness," "the glint in the eye." The panel supported my belief that it is wrong to imagine effective policymaking as devoid of passion, anger, craziness. Passions are going to be there inevitably, so you might as well understand that we could use them, not just deplore them and try to expunge them.

What excites people's passions, I think, are their values - the images of justice that they'd like to see translated into action. The anger that comes from indignation, from being badly treated, from the sense of being part of an unjust system turns out to be enormously useful in mobilizing oneself and others to take a particular action. Values associated with conceptions of justice are important in driving reforms. As a purely logical matter, one cannot decide what to do simply on the basis of fact. You have to have the fact attached to a value. From there the question becomes a political matter, when we determine what are the values that we care about, in the operation of the criminal justice system or in the organization of society.

In much of its work, the Commission focused on empirical questions of what works. But I think a lot of what animated enthusiasm for the Commission's vision of social justice (and criminal justice) was an idea about justice and about what society wanted and expected as justice. The Commission's view was based on a normative appeal to an ideal. I think today we have a different normative idea of what constitutes justice in this country than we had earlier. I do not believe this idea will be rooted out only by additional facts but by a different argument about values, about the kind of society we want to be, and about the kind of justice we want. 
The central research and development model. I want to say one word about what I describe as the central $R \& D$ model. I think for a long time our picture of the way knowledge enters criminal justice decisionmaking/ policymaking was a picture of academics working hand in glove with the Federal Government to develop ideas, to test them, and, once they were proven to work, to disseminate them. A lot of our justice institutions were set up with that kind of understanding, and for a long time I believed in this model.

The difficulty is I have never seen it work. What I've learned in 20 to 30 years of trying to interact with the world and make what contributions I can is that I am usually behind the best practitioners. The practitioners who are facing the problems are often doing what I haven't thought of. Often my job as an academic is to scurry around behind them and explain to everybody else why what they're doing is interesting.

The Crime Commission's contribution to leadership. I do believe the Crime Commission defined the forms of professionalism we have today and established the basis for the development of talented professionals in the criminal justice field. A lot of the imagination and brains, the glints in the eye, and the creativity and "craziness" necessary to find solutions to today's problems are now within the practice field, not just in academia. That is an enormous asset.

All of us who benefited from the educational programs created by the Commission (myself included) grew up with the legacy of the Commissionthe spirit of authorization, the pursuit of justice, the quest for knowledge. All of us felt we had the opportunity to imagine and to work out for ourselves what it meant to produce justice. There are at least three concepts of professionalization-technically competent people, people committed to the right values, and people who feel authorized to imagine and act in their particular location to deal with the problems they see right in front of them. What we heard in our discussions today is recognition of the decentralization and spread of leadership in criminal justice. Leadership now comes not just from national commissions but also from those in the field in all the Nation's communities. The authorization to experiment, to do the work, has spread very widely, and it is due largely to the impetus provided by the Commission.

\section{Building on the Commission's work}

The Commission reminded us of some important values to guide us in reforming the criminal justice system, controlling crime, and reconstructing society. Those values included respect for individual rights; the determination to protect liberty and to use State authority sparingly; the ambition to ensure that when we use State authority we do so fairly; and the necessity of acting outside the criminal justice system to produce social justice as well as a certain kind of criminal justice. That was the course the Commission set us on, and it was the right course.

Today's course involves producing justice and constructing relationships, in addition to protecting freedoms. It includes engaging communities and government agencies as well as ensuring fairness by operating across the criminal justice system. It means using the criminal justice system to strengthen the institutions that supply social justice as well as using it to control crime. And it means a more intense and differentiated focus on prevention as well as on control.

The final legacy of the Crime Commission, and the one that has made us feel the saddest, involves social justice. As I've stated, part of the Commission's teaching was the importance of producing social justice as well as criminal justice. I think a lot of the pain we have felt during this symposium comes from our awareness of society's retreat from its commitment to producing social justice. Part of the pain comes from the fact that as society has retreated from this commitment, criminal justice institutions are given more rather than fewer resources. Thus, those of us who work in the criminal justice system find our lives enriched while the rest of society and its other institutions are shrinking. This violates what we think is true and important about how society ought to be constructed. I am here, energized, animated, excited about the prospects of using criminal justice institutions to contribute to society, at precisely the same time as the other institutions key to achieving what we want to achieve as a society are being cut back deeply.

So I come out of this symposium with the excitement and enthusiasm that come from working on institutions I care about deeply and that I think are socially important and valuable. At the same time, I end this meeting with a profound sense of shame and regret about the failure of society to attend to the other important teaching of the Crime Commission report: Without social justice, ultimately, there can be no criminal justice. 


\title{
Comparing Drug Purchase and Use Patterns in Six Cities
}

\author{
A summary of research conducted by K. Jack Riley under the joint auspices of the \\ National Institute of Justice and the Office of National Drug Control Policy
}

This research study was designed to elicit information on practical issues and policy implications of different drug market patterns. Information derived from the study can help policymakers identify factors that affect the availability of narcotics by providing insights on how drug market participation differs and how users and markets are affected by certain conditions.

Because the cities selected for the study were chosen for their high heroin prevalence, and because the sample consisted entirely of individuals who had been arrested, study findings cannot be generalized to other cities or to other populations. It is highly likely, in fact, that the drug use and procurement patterns of users in other cities-as well as of users in the study cities who have not been arrested-are very different from those of the study participants.

In 1993 and 1994 (prior to this study) the Office of National Drug Control Policy (ONDCP) demonstrated that various features of heroin market activity, including the length of time it takes users to locate and purchase the drug, could be researched through interviews with drug users and that such interviews could provide policyrelevant data. In 1995 ONDCP, in collaboration with the National Institute of Justice (NIJ), extended this analysis to include two additional drugs - powder cocaine and crack cocaine. The extended analysis, known as the procurement study, was executed as an addendum to NIJ's Drug Use Fore- casting (DUF) program (now known as the Arrestee Drug Abuse Monitoring program) and explored additional features of drug market participation, both within and across drug types and within and across cities.

\section{Study methods}

The DUF interview has fewer than 30 questions and is conducted with recent arrestees in 23 cities nationwide. It provides major demographic and descriptive data, including age, gender, race or ethnicity, level of education, living arrangements, source and amount of income, marital status, drug treatment history, and recent criminal behavior. A drug test is used to validate self-reports of recent drug use. The procurement study selected six DUF sites noted for having a high heroin prevalence: Chicago; Manhattan; Portland, Oregon; San Antonio; San Diego; and Washington, D.C. DUF participants who had reported using powder, crack, or heroin within the previous 30 days were eligible for the procurement study. Of the 8,981 individuals who participated in DUF during the study period (from the third quarter of 1995 through the second quarter of 1996), more than 2,900 were eligible for the procurement study and 2,056 were interviewed.

The procurement interview consisted of approximately 100 questions and collected data on both drug purchase patterns and drug use patterns. The purchase pattern questions addressed such issues as the proximity of drug purchases to home and neighborhood, frequency of purchases, and source of income for purchases. Usage questions focused on the amount and type of narcotics typically used, frequency of use and cessation, and polydrug use patterns.

\section{A portrait of drug users}

Drug use among white and Hispanic interviewees was relatively evenly distributed across the powder cocaine, crack cocaine, heroin, and combination heroin (that is, heroin and powder or heroin and crack) markets, regardless of whether the respondent was held on drug or nondrug charges. The researchers found that blacks, whether arrested on drug or nondrug charges, primarily reported using crack cocaine.

Crack users generally reported living in shelters or on the streets more frequently than did other drug users. For example, 12 percent of crack users in Chicago reported that they had been on the street or in a shelter prior to arrest, compared with only 4 percent of heroin users; none of the powder cocaine users reported street or shelter living. A substantial percentage of respondents, across all drug categories, reported that public assistance was their primary form of income. Powder users were generally more likely to report that they were employed, either full time or part time. 


\section{Drug purchase patterns}

Crack users reported having more extensive dealer networks than either powder users or heroin users. Furthermore, both heroin users and powder users were more likely to report using a main source (one dealer from whom they usually make their purchases) than were crack users.

Most crack cocaine and heroin transactions in the cities studied occurred outdoors, and they were more likely than powder transactions to have taken place in the user's own neighborhood. Powder purchases were typically made outdoors with less frequency than either crack or heroin transactions. Fewer than half of the powder purchases occurred in the user's own neighborhood. Two cities-Chicago and Washington-had predominantly outdoor markets; in Washington, for example, the majority of all three drugs were sold outdoors. The majority of indoor transactions took place in residences; powder cocaine was purchased in business establishments more frequently than either heroin or crack.

Many (although not most) of the respondents reported that they had been unable to complete a narcotics purchase at least once in the year prior to arrest. The two most common reasons for failed transactions were inability to locate a dealer and the dealer not having a supply, except in Manhattan. In Manhattan, 64 percent of crack users, 55 percent of heroin users, and 38 percent of powder cocaine users reported that police activity impeded their drug transactions. Even so, a large majority of users in each city reported having made at least one drug purchase in the week prior to their arrest. Powder cocaine users reported the fewest number of transactions in that week, and heroin and crack users reported the highest number.

\section{Drug use patterns}

Participants in the procurement study were highly likely to test positive for drugs, indicating that they had used narcotics in the 72 hours before arrest. In all sites, 90 percent of those who said they had used crack in the past 30 days tested positive for cocaine, and more than 75 percent of those who said they had used heroin in the past 30 days tested positive for opiates. Between half and three-quarters of heroin respondents described themselves as daily users; in contrast, between 10 percent and 40 percent of powder cocaine respondents said they were daily users. The percentage of crack respondents describing themselves as daily users consistently fell between that of powder and heroin respondents, ranging from 32 percent (in Chicago) to 53 percent (in Manhattan).

In spite of the daily use reports, a substantial number of respondents in all categories reported that they had a 30day period of abstinence in the 90 days prior to arrest. In Manhattan, for example, 31 percent of crack users and 13 percent of heroin users reported such a period. Many of these people (27 percent of crack users and 31 percent of heroin users) reported that periods of abstinence were part of their regular pattern. Other commonly cited reasons for nonuse included lack of money, enrollment in treatment programs, and being "tired of [the drug] life."

\section{Policy implications}

The results of the procurement study suggest that the markets for powder, crack, and heroin differ from one another significantly in a number of ways, including purchase and use practices. The findings indicate that detailed information about drug habits and patterns would be a valuable tool for local law enforcement officials and service providers. For example, crack cocaine stands out for its significant exposure to law enforcement intervention because of the frequency with which users purchase the drug outdoors and rely on extensive networks of dealers. In addition, the study results suggest that interviewing the arrestee population is an appropriate method for exploring motivations for drug use and the consequences of policy interventions.

This a nalysis was conducted by $K$. Jack Riley, Ph.D., under the joint a uspices of the $\mathrm{N}$ a tional Institute of Justice and the 0 ffice of $\mathrm{N}$ ational Drug Control Policy (O N DC P). Dr. Riley is director of the Arrestee Drug Abuse M onitoring program at $\mathrm{N} \mathrm{IJ}$. O N DC P provided the resources to fund the project. Staff of BO TEC Analysis Corporation were instrumental in designing the interview instrument, conducting training, and cleaning and preparing the data. This summary is based on the report Crack, Pow der Cocaine, and Heroin: Drug Purchase and Use Patterns in Six U.S. Cities, a vailable in December 1997 from the $\mathrm{N}$ ational $\mathrm{C}$ riminal Justice Reference Service. Ask for N C J 167265 .

Points of view in this document do not necessarily represent the official position of the U.S. Department of Justice or the $\mathrm{O}$ ffice of $\mathrm{N}$ ational Drug Control Policy.

FS 000196 


\section{Date set for international land transportation security technology conference}

In partnership with the U.S. Department of Transportation, and in cooperation with the Department of State, the National Institute of Justice (NIJ) will sponsor a conference on technologies developed primarily for use by law enforcement that also can be applied to land transportation security against terrorism. The conference will be held in Atlanta, Georgia, April 7-9, 1998. Information can be obtained from conference organizer Jim Scutt of Eagan, McAllister and Associates, 703-820-8707, ext. 227.

\section{Restorative justice- final in the series of regional symposiums}

Restorative justice is a promising approach to criminal justice that takes a critical look at the current retributive system of justice and proposes to integrate crime victims - whether individuals or communities - into the system and also meet the need for offender accountability. Last year NIJ, with other Office of Justice Programs components and the National Institute of Corrections, sponsored a national symposium in which policymakers and practitioners explored the topic. A series of five followup, regional symposiums are being held to examine restorative justice in more depth; the last will be taking place in Austin, Texas, January 11-13, 1998. In addition to Texas, the region covered includes Alabama, Arkansas, Florida, Georgia, Louisiana, Mississippi, North Carolina, South Carolina, Tennessee, and Virginia. For more information, contact the Institute for Law and Justice at 703-684-5300.

\section{Law enforcement technology showcased at NIJ Summer Institute}

The latest advances in technology available for law enforcement were presented at NIJ's Summer Institute for Law Enforcement Technology. The participants, all of whom were officers involved in promoting the use of technology in their departments, represented a cross-section of the Nation's police and sheriff's departments and other enforcement agencies. They came to Washington, D.C., for a week in August 1997 to present what they felt were the successes (and failures) of technologies they have adopted and to find out what other law enforcement agencies are using and with what success. Representatives from NIJ and several Federal agencies, including the Federal Bureau of Investigation (FBI), the Drug Enforcement Administration (DEA), and the Bureau of Alcohol, Tobacco and Firearms (ATF), briefed participants on technologies now being developed and used at the Federal level.

Participants' technology needs were fairly consistent from agency to agency: They were interested in ways to stop fleeing vehicles, means to limit the effect of bombs, methods for developing statewide informationsharing networks, software for documenting crimes, better systems to communicate among individual officers in vehicles as well as at the department level, and ways to facilitate officer training. NIJ's Office of Science and Technology has been working in several of these areas to develop new technologies or adapt already existing technologies for law enforcement. One of the most beneficial aspects of the Institute was the opportunity for participants to assist each

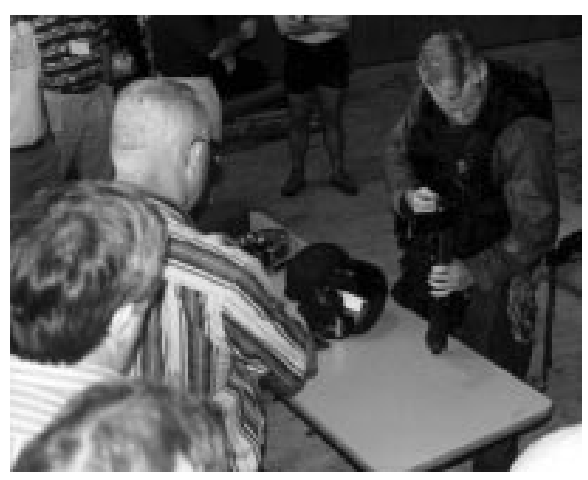

An FBI hostage rescue team member demonstrates one of the Bureau's assault weapons at NIJ's Summer Institute for Law Enforcement Technology.

other in resolving problems during the "Peer Review Problem Solving" session.

The Summer Institute is the first of what NIJ plans as an annual event that will foster information exchange among local, county, and State enforcement agencies, as well as feature briefings on developments at the Federal level. Information may be obtained from Kevin Jackson, Acting Director of NIJ's Technology Assistance Division, which administers the National Law Enforcement and Corrections Technology Centers. He can be reached at 202-307-2956, or by e-mail at jacksonk@ojp.usdoj.gov.

\section{Crime mapping- NIJ holds forum for exchanging information}

Law enforcement officers, crime analysts, geographers, researchers, and other criminal justice practitioners convened in Denver this fall to share information about how computerized crime mapping can aid both in controlling crime and in conducting criminological research. The conference, 
sponsored by NIJ's new Crime Mapping Research Center (CMRC), drew approximately 400 participants, who spent 3 days learning about the best mapping practices in law enforcement, the use of GIS (Geographic Information Systems) in community policing, and how law enforcement agencies can work with researchers in using crime mapping. Workshops on introductory and advanced GIS, cartography, and spatial and temporal analysis of crime patterns were held as learning sessions for participants.

Over the past decade, the criminal justice community has begun to reap the valuable analytic benefits of GIS technology. This powerful tool enhances the ability of researchers and practitioners to identify hot spots of criminal activity and analyze the complex spatial patterns of crime and criminal behavior. NIJ established the Crime Mapping Research Center in 1996 to promote research, evaluation, development, and dissemination of GIS technology for criminal justice applications.

A summary of the conference, which NIJ plans to hold annually, is available online at www.nlectc.org/cmrc. For more information about this or other Center activities, write to the National Institute of Justice, 810 Seventh Street N.W., Washington, DC 20531; or send an e-mail to CMRC@ojp.usdoj.gov. An electronic listserv, "Crimemap," is available to those interested in online discussions about computerized mapping technologies as they are used in criminal justice activities. To subscribe, send an e-mail message to listproc@aspensys.com, leave the subject line blank, and in the body of the message type: subscribe crimemap <your name>.

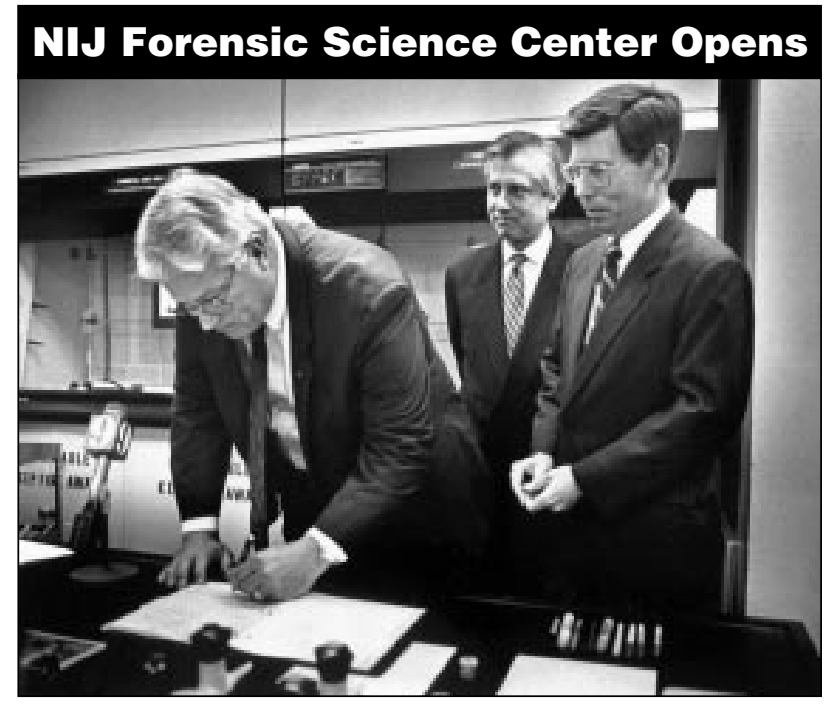

Dr. John Hitt, President of the University of Central Florida (left), signs papers establishing the Forensic Science Center, as Jeremy Travis, Director of the National Institute of Justice (center) and Congressman Bill McCollum of Florida (right) look on.

Photo courtesy of the University of Central Florida

A national center for research on forensic matters was recently established with NIJ support. Based at the University of Central Florida in Orlando, the National Center for Forensic Science (NCFS) was formally introduced to the law enforcement community in May 1997. The opening of the new center expands NIJ's network of technology centers, the National Law Enforcement and Corrections Technology Center (NLECTC) system.

Established as a forensic laboratory facility, the Center will initially focus on arson and explosion research, training support, and technical assistance for law enforcement agencies and laboratory analysts. Other goals include developing guidelines for field investigators and analysts, promoting information exchange (via an Internet web site), and creating facilities such as an instrument development laboratory, an outdoor test site, and a resource center. The university has coordinated with forensic specialists from the FBI and the Bureau of Alcohol, Tobacco and Firearms in planning NCFS activities that will complement the ongoing initiatives of these agencies and avoid duplication of effort.

NCFS can be contacted by mail at the University of Central Florida, P.O. Box 162367, Orlando, FL 32816; by phone at 407-823-6469; by fax at 407-823-3162; or by e-mail at natlctr@pegasus.cc.ucf.edu.

\section{The "Crack Decade" in perspective}

The response to the crack cocaine epidemic of the past decade was reviewed recently in a conference sponsored by NIJ and the National Institute on Drug Abuse. Titled "The Crack Decade: Research Perspectives and Lessons Learned," the November 4-5 conference, held in Baltimore, attracted some 100 participants, among them researchers in criminol- ogy and public health as well as policymakers, community leaders, and representatives of the press. Featured speakers included eminent researchers David Musto and Peter Reuter. The responses of researchers in criminal justice and public health and of law enforcement, the community, and the media were reviewed, and future research needs were explored in depth. NIJ plans to publish the proceedings of the conference. 
The following articles are based on studies sponsored by NIJ. Copies are available on loan from the National Criminal Justice Reference Service (NCJRS); in some cases photocopies may be obtained. For information on availability, call NCJRS at 800-8513420; or send an Internet e-mail to askncjrs@ncjrs.org. Please cite accession number.

"Effect of Weather and Temporal Variations on Calls for Police Service," American Journal of Police 15(1)(1996):23-43, by E.G. Cohn, grant number 86-IJ-CX-0037, accession number (ACCN) 165844. This article discusses the results of research into short-term variations in police service calls during 1985, 1987, and 1988 in Minneapolis, Minnesota, based on weather changes and time of day. Findings indicate that the time of day as well as the day of the week or the month were the best indicators of the number of calls to the police. Police service calls increased during afternoon and evening hours, on weekends, in the spring and summer months, and at night.

"Gang Violence in Chinatown," by K.-L. Chin, in Gangs in America, 2d ed. (1996), grant number 89-IJ-CX0021, ACCN 165304. This article, which reports the findings of a study of 62 former or active members of Chinese gangs, examines the extent of gang violence in New York City's Chinatown. Findings show that intergang violence was the most common type of violence, with drug use, drug trafficking, protection rackets, and community politics appearing to have little influence on gang violence in the area studied.

"Measurement of Children's Exposure to Violence: A Rasch Analysis," International Journal of Methods in Psychiatric Research 6(161)(1996):
1-8, by D.J. Kindlon et al., grant number 93-IJ-CX-K005, ACCN 165450. The authors interviewed individuals about their exposure to violence and subjected their responses to a measure of exposure called the Rasch model. Findings indicate models such as Rasch may be applied to other multi-item assessments of social behavior and experience.

"Neighborhoods and Violent Crime: A Multilevel Study of Collective Efficacy," Science 277(August 15, 1997):1-7, by Robert J. Sampson, Stephen W. Raudenbush, and Felton Earls, grant number 93-IJ-CX-K005, ACCN 167257. A report from the Project on Human Development in Chicago Neighborhoods reveals lower rates of violence in urban neighborhoods characterized by "collective efficacy." The Project is a long-term study, sponsored by NIJ, the MacArthur Foundation, the U.S. Department of Education, and the $\mathrm{Na}$ tional Institute of Mental Health, that is identifying the antecedents to violence in several thousand children and young adults living in 80 Chicago neighborhoods. The researchers examined mutual trust and willingness to intervene in supervising children and maintaining public order (which they term collective efficacy) rather than such traditionally investigated factors as poverty and ethnicity. They found that neighborhoods characterized by these measures of social cohesion tend to have lower levels of crime, although they caution that the recognition that this factor matters does not imply that social inequalities can be neglected.

"Psychopathy and Violent Behaviour in Abused and Neglected Young Adults," Criminal Behaviour and Mental Health 6(3)(1996):253-271, by B.L. Weiler and C.S. Widom, grant numbers RO1-MH49467, 86-IJ-CX-
0033, 89-IJ-CX-0007, and 93-IJCX-0031, ACCN 165719. This article discusses the findings of a study of abused and neglected individuals who suffered childhood physical and sexual abuse and/or neglect in a metropolitan area of the Midwestern United States. Findings reveal a clear connection between early childhood victimization and psychopathy and suggest that the relationship between childhood victimization and violence in some individuals may be mediated through psychotherapy.

"Risk Factors Associated With Recidivism Among Extrafamilial Child Molesters," Journal of Consulting and Clinical Psychology, 65(1)(1997):141149, by R.A. Prentky, R.A. Knight, and A.F.S. Lee, grant numbers 92-IJCX-K032 and 94-IJ-CX-0031, ACCN 165738. The authors examine followup data on more than 100 child molesters discharged from the Massachusetts Treatment Center between 1960 and 1984 to assess the ability of these factors to predict the risk for recidivism. They conclude that juvenile and adult antisocial behavior, paraphilia, and low amount of contact with children predicted nonsexual victiminvolved and violent recidivism.

\section{Also of interest:}

"Clinical and Actuarial Predictions of Violence," by John Monahan, in Modern Scientific Evidence: The Law and Science of Expert Testimony, vol. 1, ed. D. Faigman et al., St. Paul, Minnesota: West Publishing Company, 1997:300-318, ACCN 167258.

The study investigates the relationship between mental disorder and violence. The researcher found that whether the measure is the prevalence of violence among the disordered or the prevalence of disorder among the violent, 
and whether the people studied are those selected for treatment as inmates or patients in institutions or people randomly chosen from the community, there appears to be a greater-thanchance relationship between mental disorder and violence. However, the researcher cautions that none of the data support sensationalized caricatures of the mentally disordered or the shunning of former patients. More- over, compared to the magnitude of risk from the combination of male gender, youth, and substance abuse, for example, the risk of violence presented by mental disorder is modest.

\section{Recent Nij Publications}

The following recent and forthcoming NIJ publications are available from NCJRS in both online and hardcopy formats. For ordering information, call NCJRS at 800-851-3420; or send ane-mail to askncjrs@ncjrs.org.Electronic copies can be downloaded from the Justice Information Center Web site: http://www.ncjrs.org.

Building Knowledge About Crime and Justice: Research Prospectus 1998, U.S. Department of Justice, National Institute of Justice, November 1997 , 22 pp., NCJ 167570. NIJ outlines its plans for addressing its major longrange research and development goals in the year ahead. NIJ-sponsored research in crime, the criminal justice system, and science and technology for law enforcement engages many of the Nation's top researchers. Projects are selected from proposals submitted in response to an "open solicitation" for investigator-initiated research and to several requests for proposals on specific topics, issued throughout the year. NIJ sponsors basic research, demonstration programs, technology development, and identification of innovative programs and effective public policy. Also described is NIJ's program of dissemination to the field.
The Crime of Stalking: How Big Is the Problem? Research Preview, summary of a presentation by Patricia Tjaden, U.S. Department of Justice, National Institute of Justice, October 1997, 4 pp., FS 000186. This publication presents the findings of a survey on stalking, conducted as part of the National Violence Against Women Survey, a collaboration between NIJ and the Centers for Disease Control and Prevention. Stalking was found to be a bigger problem than previously thought, affecting about 1.4 million victims annually. Women are much more likely to be stalked than men, and in the majority of incidents the stalker is known to the victim. The survey also reveals that although stalking usually stopped within 1 to 2 years, victims often faced much longer term consequences, both social and psychological. A 60-minute VHS videotape (NCJ 163921), "Stalking in America: Findings From the National Violence Against Women Survey," is also available.

\section{Criminal Behavior of Gang Members} and At-Risk Youths, Research Preview, summary of a presentation by $\mathrm{C}$. Ronald Huff, U.S. Department of Justice, National Institute of Justice, January 1998, 4 pp., FS 000190. This publication presents the findings of multiagency studies of the effects of gang membership on criminal behavior. Examining four cities, the researcher found that gang members were considerably more likely to be involved in crime, especially violent and drug-related crime, than at-risk youths of similar ages who were not gang members. Gang membership also was associated with greater involvement with guns, including ownership and use in crimes. A 60-minute VHS videotape (NCJ 164725), "Criminal Behavior of Gang Members," is also available.

Criminal Justice Research Under the Crime Act-1995 to 1996, Research Report, U.S. Department of Justice, National Institute of Justice, September 1997, 85 pp., NCJ 166142. This report summarizes research and evaluation sponsored by the National Institute of Justice under the Crime Act in its first 2 years. Areas of focus are community policing, sentencing and corrections (including boot camps), violence against women, and drug courts.

Drugs, Alcohol, and Domestic Violence in Memphis, Research Preview, summary of a presentation by Daniel 
Brookoff, U.S. Department of Justice, National Institute of Justice, October 1997, 4 pp., FS 000172. The researcher studied the prevalence of and contributing factors to domestic violence in Memphis. Among the findings were that almost all assailants had used drugs or alcohol the day of the assault, two-thirds of assailants were on probation or parole at the time of the assault, and a majority of battering incidents involved the assailant's use or display of a weapon. A 60-minute VHS videotape (NCJ 163056), "Drug Use and Domestic Violence," is also available.

Homicide in Eight U.S. Cities: Trends, Context, and Policy Implications, Research Report, by Pamela K. Lattimore et al., U.S. Department of Justice, National Institute of Justice, December 1997, 150 pp., NCJ 167262. This report from the intramural research program of the National Institute of Justice presents an analysis of homicide patterns in eight cities, some with increasing and others with decreasing homicide rates, examining the extent to which various factors (such as demographic trends and economic conditions) are associated with the homicide trends. A summary of the full report has also been published: A Study of Homicide in Eight U.S. Cities: An NIJ Intramural Research Project, Research in Brief, by Pamela K. Lattimore et al., U.S. Department of Justice, National Institute of Justice, December 1997, 12 pp., NCJ 167263.

Immigrant Populations as Victims, Research in Brief, by Robert C. Davis and Edna Erez, U.S. Department of Justice, National Institute of Justice, January 1998, 8 pp., NCJ 167571. This report presents the findings of a study of the problems recent immigrants encounter as "consumers" of criminal justice services and ways to improve the criminal justice response to them. Interviews with law enforcement officials revealed that immigrants reported crimes less frequently than other victims, with domestic violence the most underreported crime. Officials also believe that immigrants face greater hardships than other victims when reporting crime or attending court, primarily because of language barriers and cultural differences; interviews with immigrants interviewed confirmed these findings.

Measuring What Matters: Part Two: Developing Measures of What the Police Do, Research in Action, by Thomas V. Brady, U.S. Department of Justice, National Institute of Justice, November 1997, 16 pp., NCJ 167255. "Measuring What Matters" was a series of discussions, sponsored by NIJ and the Office of Community Oriented Policing Services' Policing Research Institute, in which police chiefs, researchers, and leaders of community organizations explored the development of police effectiveness measures. Among the issues discussed were the feasibility of constructing an index for minor crimes (disorders) similar to that of the FBI's Uniform Crime Reports, the attributes of a "healthy" police organization, and ways to measure police corruption. In preparation at NIJ is a volume of the papers presented during the three Policing Research Institute sessions.

National Evaluation of G.R.E.A.T., Research in Brief, by Finn-Aage Esbensen and D. Wayne Osgood, U.S. Department of Justice, National Institute of Justice, December 1997, 8 pp., NCJ 167264. This report presents early findings from a comprehensive evaluation of the Gang Resistance Education and Training (G.R.E.A.T.) program, a national gang prevention effort aimed at middle school students. Preliminary results support continuation of the program and demonstrate that trained law enforcement personnel can serve as prevention agents in addition to being enforcers of the law.

The NIJ Publications Catalog, 19961997, U.S. Department of Justice, National Institute of Justice, November 1997, 64 pp., NCJ 166144. The Cata$\log$ lists publications and videotapes produced by the National Institute of Justice between January 1996 and June 1997, organized alphabetically by subject. For each publication, the title, author, number of pages, identification number for ordering, availability information, and a brief description are included. Most items are free, and many can be obtained electronically.

NIJ Publications Catalog: Sixth Edition, 1986-1996, U.S. Department of Justice, National Institute of Justice, November 1997, 32 pp., NCJ 167244. The Catalog lists all publications and videotapes produced by NIJ between January 1986 and December 1996. Titles are listed alphabetically by subject; each listing includes title, author, number of pages, ordering number, and print and electronic availability. Most items are free.

The Orange County, Florida, Jail Education and Vocational Program, Program Focus, by Peter Finn, U.S. Department of Justice, National Institute of Justice, December 1997, 50 pp., NCJ 166820. The unusually intensive educational and vocational program operated for jail inmates by the Orange County, Florida, Corrections Division includes multiple program components, among them adult basic education, GED preparation, job training, and substance abuse education. Combined with direct supervision and behavioral incentives, the program has reduced staffing needs, construction costs, and violent incidents while increasing inmates' educational levels 
and job readiness. There is also evidence the program has reduced reoffending.

Policing in Emerging DemocraciesWorkshop Papers and Highlights, Research Report, U.S. Department of Justice, National Institute of Justice, and U.S. Department of State, Bureau of International Narcotics and Law Enforcement Affairs, October 1997, 120 pp., NCJ 167024. The publication presents the papers and other addresses delivered at a workshop on policing in emerging democracies held December 14-15, 1995, in Washington, D.C.

Rise of Hallucinogen Use, Research in Brief, by Dana Hunt, U.S. Department of Justice, National Institute of Justice, October 1997, 12 pp., NCJ 166607. This study analyzing hallucinogenic drug use points to evidence of these drugs' popularity among nonminority high school and college students. Although the rising use of hallucinogenic drugs is not associated with severe threats to law enforcement, there are public health problems posed by users who drive while under their influence.

"Three Strikes and You're Out": A Review of State Legislation, Research in Brief, by John Clark, James Austin, and D. Alan Henry, U.S. Department of Justice, National Institute of Justice, September 1997, 16 pp., NCJ 165369. In this study, the effectiveness of the "three strikes" laws in California and Washington State is evaluated and the differences among new three-strikes laws enacted in 24 States are examined. The researchers also compare the new laws to the States' preexisting provisions on repeat offender sentencing. Early evidence shows that, with the exception of California's law, most will have minimal impact on those States' prison systems because they were drafted to apply only to the most violent repeat offenders.

Violence Among Middle School and High School Students: Analysis and Implications for Prevention, Research in Brief, by Daniel Lockwood, U.S. Department of Justice, National Institute of Justice, October 1997, 12 pp., NCJ 166363. The study analyzes violent incidents among young people, with a focus on the pattern of events, "opening moves," relationships among antagonists, and goals and justifications. The analysis can be used to indicate areas for intervention and prevention.

Visibility and Vigilance: Metro's Situational Approach to Preventing Subway Crime, Research in Brief, by Nancy G. La Vigne, U.S. Department of Justice, National Institute of Justice, November 1997, 12 pp., NCJ 166372. In a report from the intramural research program of the National Institute of Justice, the lower-thanexpected crime rates for the subway system (Metro) of Washington, D.C., are explained by design, management, and maintenance characteristics that incorporate principles of situational crime prevention and Crime Prevention Through Environmental Design (CPTED).

\section{NEW LIST OF CURRENT NIJ RESEARCH PROJECTS}

All the current research, evaluation, and program development projects sponsored by N IJ constitute the agency's "research portolio." This publication, available online and in hard copy, includes grants and contracts, interagency a greements, fellow ships, and research conducted intra murally by $\mathrm{N}$ IJ staff.

1997 NIJ Research Portfolio, Research in Brief, U.S. Department of Justice, $\mathrm{N}$ ational Institute of Justice, N ovember 1997, 40 pp., N C J 166374 . The Portfolio presents all ongoing research, evaluation, and program development projects sponsored by the Institute through June 30,1997 . Each project listed is part of $\mathrm{N} \mathrm{IJ's} \mathrm{overall} \mathrm{strategic} \mathrm{plan} \mathrm{to}$ respond to the $\mathrm{N}$ ation's critical criminal justice concerns.

The Portfolio is organized into four main topic areas reflecting the breadth of concerns of the Institute and the researcher and practitioner communities: criminal behavior, crime control and prevention, the criminal justice system, and technology research and development.

Researchers and others will find the Portfolio useful as a guide to $\mathrm{N} \mathrm{IJ'S}$ research priorities. The Institute's approach to research is described in the N IJ Prospectus. An "open" solicitation invites investigator-initiated proposals in broadly defined areas. The Institute also issues separate, focused solicitations for research on specific issues and programs. 
The following final reports-in manuscript form as submitted by authorspertain to completed NIJ-sponsored research projects. The reports are available from NCJRS through interlibrary loan and as photocopies. For information about fees, call NCJRS at 800-851-3420.

"DNA Legal Training and Technical Assistance Unit," by Christopher Asplin and Renee Kostick, American Prosecutors Research Institute, ACCN 167259, 1997, 8 pp., grant number 95-IJ-CX-0002.

"Efforts by Child Welfare Agencies to Address Domestic Violence: The Experiences of Five Communities," by L.Y. Aron and K.K. Olson, ACCN 166054, 1997, 158 pp., grant number 95-IJ-CX-A037.

"The Evaluation of Forensic DNA Evidence," by the National Research Council, ACCN 166538, 1997, 244 pp., grant number 93-IJ-CX-0008.

"Police Response to Gangs: Case Studies of Five Cities," by D.L. Weisel and E. Painter, ACCN 165614, 1997, 96 pp., grant number 90-IJCX-K008.

"Project on Human Development in Chicago Neighborhoods," by F.J. Earls and S.L. Buka, ACCN 163495, 1997, 118 pp., grant number 93-IJCX-K005.

"Research in Action Partnerships: Outreach and Application of Research Findings; Dissemination of Family Violence Research to Justice System Practitioners," American Bar Association Center on Children and the Law, ACCN 165203, 1997, 62 pp., grant number 96-IJ-CX-K002.

"Violence Against Women Act of 1994: Evaluation of the STOP For- mula Grants to Combat Violence Against Women," by M.R. Burt et al., ACCN 166312, 1997, 93 pp., grant number 95-WT-NX-0005.

"Coordinated Community Responses to Domestic Violence in Six Communities: Beyond the Justice System," Final Report and Summary, by S.J. Clark, M.R. Burt, M.M. Schulte, and K. Maguire, ACCN 166055, 1996, 168 pp., and ACCN 166056, 1996, 21 pp., grant numbers 95-IJ-CX-A037 and HHS-100-95-0021.

"Day Reporting Centers as an Intermediate Sanction: Evaluation of Programs Operated by the ATTIC Correctional Services," by A. Craddock and L.A. Graham, ACCN 165726, 1996, 169 pp., grant number 93-IJ-CX-4048.

"Police Officer Orientation and Resistance to Implementation of Community Policing," by P. McCold and B. Wachtel, ACCN 165617, 1996, 26 pp., grant number 95-IJ-CX-0042.

"Boot Camps, Work Camps, and Community Needs: A Restorative Justice Perspective on Correctional Objectives," by G. Bazemore and T.J. Quinn, ACCN 165603, 1996, 14 pp., grant number 95-IJ-CX-0016.

"How Are Adult Felony Sex Offenders Managed on Probation and Parole? A National Survey," by K. English et al., ACCN 163388, 1996, 124 pp., grant number 92-IJ-CX-K021.

"Statutory and Constitutional Protection of Victims' Rights: Implementation and Impact on Crime Victims," Final Report and Executive Summary, National Victim Center, ACCN 166461, 1996, 200 pp., and ACCN 166460, 1996, 6 pp., grant number 93-IJ-CX-K003.
"Drug Court Planning and Implementation: Selected Operational Materials," American University School of Justice, College of Public Affairs, ACCN 165499, 1995, 276 pp., grant number 95-DC-MX-K002.

"Pepper Spray Evaluation Project: Results of the Introduction of Oleoresin Capsicum (OC) into the Baltimore County, MD, Police Department," International Association of Chiefs of Police, ACCN 164118, 1995, 100 pp., grant number 92-IJ-CX-K026.

\section{Feature Report}

\section{Automated Booking in Federal Law Enforcement}

"Evaluation of JABS: Joint Automated Booking System Program," by PRC Inc., Reston, Virginia, ACCN 167884, November 1996, grant number 95-IJ-CX-0040.

Booking offenders into the Federal criminal justice system promises to become more efficient thanks to a new, automated system for collecting, storing, and retrieving information essential to investigators and prosecutors. A recently conducted NIJ evaluation of a pilot program in south Florida determined that the system is fast and easy to use, produces highquality information and, because it creates a single electronic record, increases accessibility and eliminates duplication.

With the Joint Automated Booking System (JABS), users enter booking information, which can then be retrieved electronically. The information includes personal data about the offender, mugshots and fingerprints (which are digitized), and other evidence. A key component of JABS is its information-sharing capability: Once entered, the data can be sent to 
other Department of Justice law enforcement agencies.

In an NIJ-sponsored evaluation conducted by PRC Inc., researchers examined the effectiveness of the system as used by south Florida-based agents of the Bureau of Prisons, DEA, FBI, Immigration and Naturalization Service, and U.S. Marshals Service. The key question, whether JABS represents an improvement over manually performing these booking tasks, was answered in the affirmative. JABS was found to be easy to use: More than two-thirds of those who used the system said they were able to do so without seeking help. JABS reduces the time it takes to complete bookings: On average, a practitioner using JABS can complete the booking data entry in about 15 minutes, compared to about $25 \mathrm{~min}$ utes without JABS. The data JABS produces are high-quality: The practitioners who used the system said it generates better photographs, fingerprints, and better recorded personal data on offenders.

JABS not only offers these benefits but also raises the possibility of expanding or incorporating this method of data collection and exchange into current and future national law enforcement systems. The system does present some opportunities for im- provement, however, and the evaluators offered recommendations to pursue them. For example, the prospect of JABS becoming a national system depends on defining operational and technical requirements, developing system architecture and standards, and methods for ensuring maintenance, security, and support. The researchers also suggest that if the south Florida JABS "laboratory" were further developed, it could become the pattern for expanding the system nationwide, and in user training the focus could shift to the use of JABS as an investigative tool in addition to a data collection tool.

\section{NIJ solicitations for research}

All current solicitations for research and evaluation can be obtained electronically from the Justice Information Center at www.ncjrs.org/ fedgrant.htm\#nij or in hardcopy format from the U.S. Department of Justice Response Center at 800-421-6770 (in the Washington, D.C., area at 202-307-1480). Application forms and guidelines for submitting proposals are also available.

\section{Investigator-initiated research-solicitation forthcoming}

In its "open solicitation" for research, NIJ invites prospective applicants to submit proposals for research in any topic relevant to State or local criminal justice policy or practice. The next solicitation for investigator-initiated research will be issued early in 1998 . Typically, the grants range from $\$ 25,000$ to $\$ 300,000$ and last for 1 to 2 years. Proposals are accepted twice yearly; due dates will be noted in the forthcoming solicitation. Researchers may wish to review the current open solicitation, which is available from the above sources.

\section{Requests for VAWA research to come}

Solicitations for research on violence against women will be issued by NIJ in the near future. Several specific solicitations will request proposals for research in areas such as domestic violence and arrest policies. To receive copies of the solicitations, call the National Criminal Justice Reference Center at 800-851-3420; write to NCJRS at P.O. Box 6000 , Rockville, MD 20849-6000; or e-mail askncjrs@ncjrs.org and ask that your name be added to the Family Violence and Violence Against Women mailing list (\#428). 


\section{NIJ's "Perspectives" dates set}

In NIJ's lecture series, "Perspectives on Crime and Justice," the country's foremost criminologists are invited to examine major crime and justice issues through the lens of public policy. The schedule for the second year of the series, which begins in December 1997, is as follows:

- George Kelling, "Crime Control, the Police, and the Cultural Wars: Broken Windows and Cultural Pluralism," December 2, 1997.

- Randall Kennedy, "Race, the Police, and 'Reasonable Suspicion,' " February 3, 1998.

- David Musto, "The American Experience with Stimulants and Opiates," March 3, 1998.

- Joan Petersilia, "If Not Prison, What? Assessing Alternative Punishments," April 1, 1998.

- Philip Cook, "The Epidemic of Youth Gun Violence,” May 5, 1998.

The collected lectures from the series' first year have been published as: Perspectives on Crime and Justice: 19961997 Lecture Series, Research Report, U.S. Department of Justice, National Institute of Justice, November 1997. This volume contains the papers presented by James Q. Wilson, Peter Reuter, Mark H. Moore, Cathy Spatz Widom, and Norval Morris. Copies are available from the National Criminal Justice Reference Service (order NCJ 166609). The 1997-1998 lecture series will also be published.

\section{Arrestee Drug Abuse Monitoring (ADAM) program}

Since its founding in 1987, NIJ's Drug Use Forecasting (DUF) program has generated data that have played an important role in constructing the national picture of drug abuse. In major urban areas nationwide, DUF tests booked arrestees for recent drug use, with the results made available to State and local policymakers and the data used by researchers to study the drugs-crime nexus.

The role of DUF as a "research platform" to explore the relationship of drugs and crime has grown over the years. Researchers have used DUF data to inquire into arrestee gun use, drug markets, and factors such as gender and race as they relate to drug use. DUF's utility as a research platform was one rationale for its transformation in 1997 to the Arrestee Drug Abuse Monitoring (ADAM) program.

ADAM will build on DUF's success by incorporating new elements intended to significantly strengthen the value of the data. Data collection and sampling methodology will be redesigned to provide policymakers and practitioners with a rigorous basis from which to assess local drug-use trends and patterns and evaluate policy. ADAM will expand from the current 23 sites to 75 , and NIJ plans to develop local coordinating councils to generate site-based research projects and to assume a prominent role in disseminating the sites' findings. Plans also include an outreach program to collect data on drug abuse from specific populations such as those in suburban, rural, and Native American jurisdictions. Collecting data on drug use in outreach popu- lations will enhance the ability to track the development and movement of new drug epidemics.

NIJ is also working to develop international ADAM sites. These sites would provide important baseline information on world substance abuse patterns and serve as a foundation for conducting international comparative research on criminal justice and substance abuse topics. This component of ADAM will include technical assistance from NIJ to countries that participate in the international effort.

\section{Interagency approach planned for research on violence against women}

Collaboration on a long-term, 5-year research strategy on violence against women is being proposed by NIJ and the National Center for Injury Prevention and Control (NCIPC). The goal is to achieve a coordinated interagency and interdisciplinary approach to the research.

The genesis of the planned collaboration was the 1994 Crime Act. As a result of congressional and administration concern about violence against women, the Violence Against Women Act (VAWA) was included as a major part of the omnibus legislation. One VAWA component was a mandate from Congress to meet the need for empirical data by developing a systematic agenda for research on violence against women.

The research agenda was developed by the National Academy of Sciences with funding from NIJ and the Centers for Disease Control and Prevention (CDC). ${ }^{1}$ NIJ and NCIPC (a CDC 
agency) plan to work together to coordinate the approach to the issues and priorities identified in the agenda and to serve as liaison to other interested Federal agencies. The proposed partnership will link the criminal justice and public health approaches at the Federal level while avoiding duplication of effort that might occur if the agencies acted on their own.

The proposed research would cover measuring the extent of violence against women, why it occurs, and how to prevent it. Funding for the first year of the program has been approved for fiscal year 1998 .

\section{National commission will make recom- mendations on use of DNA evidence}

Responding to the extraordinary advances in DNA technology over the past 10 years that have left many criminal justice professionals without proper training and technical support, in August 1997 Attorney General Janet Reno authorized establishment of a national commission to make recommendations about the proper handling of DNA evidence in criminal cases. The commission will consider how recent advances in DNA research affect the operations of the entire criminal justice system, from crime scene through trial. Although the forensic use of DNA technology increasingly offers prosecutors an important new tool to identify criminals, there remain challenges for the scientific and justice communities. For instance, in some cases, evidence may be improperly collected or preserved; attorneys may be ill equipped to effectively question expert witnesses; judges may be uncertain about making rulings on the admissibility of DNA evidence in court.

The commission's creation can be traced to a recent study commissioned by the National Institute of Justice, Convicted by Juries, Exonerated by
Science: Case Studies in the Use of DNA Evidence to Establish Innocence After Trial (NCJ 161258), which documented several cases in which individuals who had been imprisoned later successfully challenged their convictions using DNA evidence.

Commission members will be drawn from a broad spectrum of policymakers, criminal justice professionals, and experts in the use of DNA forensic evidence. The commission will present its recommendations to the Director of the National Institute of Justice within 2 years.

\section{Note}

1. The research agenda was published as Understanding Violence Against Women, ed. Nancy A. Crowell and Ann W. Burgess, Washington, D.C.: National Academy Press, 1996. It is available from the National Academy Press at 2101 Constitution Avenue N.W., Washington, DC 20055. Phone 800-624-6242.

\section{Online Resource of Violence Prevention Programs}

Information about strategies that communities use nationwide to prevent violence is available on the World Wide Web. The Partnerships Against Violence Network (PAVNET) presents descriptions of programs in the areas of youth violence, substance abuse, and victim assistance, along with the names of program representatives and information about funding. More than 1,000 entries are listed and are regularly updated. A list of technical assistance providers and funding sources is also included, as are online links to other violence prevention resources.

PAVNET may be accessed at http://www.pavnet.org.

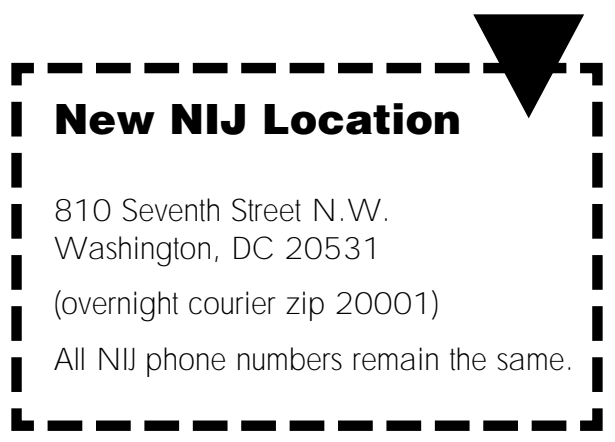




\section{Stay on the Cutting Edge of Criminal Justice Research Visit NIJ's NEW Web Site!}

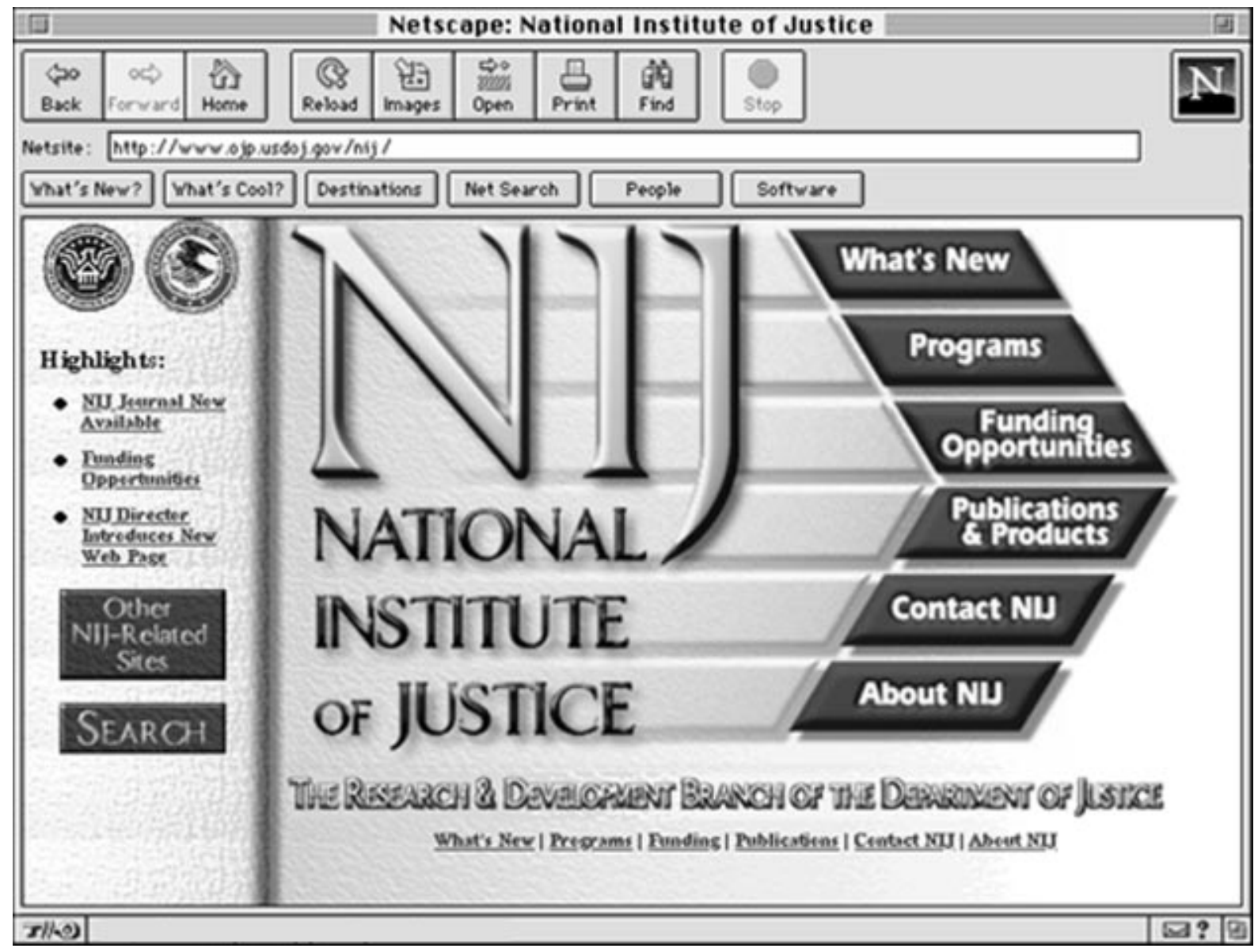

For the latest information on NIJ research, programs, and grant opportunities, visit:

\section{www.ojp.usdoj_gov/nij/}




\section{Selectie Nij Publlcatons -}

\section{Selected NIJ Publications About Policing, Drugs and Drug Testing, and DNA}

Listed below are some NIJ publications related to issues of policing, drugs and drug testing, and DNA. These products are free, except as indicated, and can be obtained from the National Criminal Justice Reference Service: telephone 800-851-3420; e-mail askncjrs@ncjrs.org; or write NCJRS, Box 6000, Rockville, MD 20849-6000.

These documents can be downloaded from the Justice Information Center World Wide Web site at http:// www.ncjrs.org, and are also accessible from the NIJ Web site at http:// www.ojp.usdoj.gov/nij/.

Please note that when free publications are out of stock, they are available as photocopies or through interlibrary loan.

\section{Policing}

Brady, Thomas V., Measuring What Matters: Part One: Measures of Crime, Fear, and Disorder, Research in Action, a joint publication of the National Institute of Justice and the Office of Community Oriented Policing Services, 1996, NCJ 162205.

Communities: Mobilizing Against Crime, Making Partnerships Work, National Institute of Justice Journal 231, August 1996.

Finn, Peter, and Julie Esselman Tomz, Developing a Law Enforcement Stress Program for Officers and Their Families, Issues and Practices, 1996, NCJ 163175.

Fleissner, Dan, and Fred Heinzelmann, Ph.D., Crime Prevention Through Environmental Design and Community Policing, Research in Action, 1996, NCJ 157308.
Gaffigan, Stephen J., and Phyllis P. McDonald, Police Integrity: Public Service With Honor, Research Report, a joint publication of the National Institute of Justice and the Office of Community Oriented Policing Services, 1997, NCJ 163811.

Mastrofski, Stephen D., et al., Law Enforcement in a Time of Community Policing, Research Preview, 1996, FS 000149.

Sadd, Susan, and Randolph M. Grinc, Implementation Challenges in Community Policing: Innovative Neighborhood-Oriented Policing in Eight Cities, Research in Brief, 1996, NCJ 157932.

Skogan, Wesley, Community Policing in Chicago: Fact or Fiction?, VHS videotape, 1995, NCJ 153273, U.S. $\$ 19$, Canada and other foreign countries $\$ 24$.

\section{Drugs and Drug Testing}

Brookoff, Daniel, Drug Use and Domestic Violence, VHS videotape, 1997, NCJ 163056, U.S. \$19, Canada and other foreign countries \$24.

Brookoff, Daniel, Drugs, Alcohol, and Domestic Violence in Memphis, Research Preview, 1997, FS 000172.

Feucht, Thomas E., and Gabrielle M. Kyle, Methamphetamine Use Among Adult Arrestees: Findings From the Drug Use Forecasting (DUF) Program, Research in Brief, 1996, NCJ 161842.

Golub, Andrew, Crack's Decline: Some Surprises Across U.S. Cities, VHS videotape, 1996, NCJ 164262, U.S. \$19, Canada and other foreign countries $\$ 24$.
Golub, Andrew Lang, and Bruce D. Johnson, Crack's Decline: Some Surprises Across U.S. Cities, Research in Brief, 1997, NCJ 165707.

Hunt, Dana, Rise of Hallucinogen Use, Research in Brief, 1997, NCJ 166607.

Mieczkowski, Tom, Hair Assays and Urinalysis Results For Juvenile Drug Offenders, Research Preview, 1997, FS 000171.

1996 Drug Use Forecasting, Annual Report on Adult and Juvenile Arrestees, Research Report, 1997, NCJ 165691.

Rhodes, William, and Michael Gross, Case Management Reduces Drug Use and Criminality Among Drug-Involved Arrestees: An Experimental Study of an HIV Prevention Intervention, Research Report, a joint publication of the National Institute of Justice and the National Institute on Drug Abuse, 1997, NCJ 155281.

Rhodes, William, Raymond Hyatt, and Paul Scheiman, Predicting Pretrial Misconduct with Drug Tests of Arrestees: Evidence From Six Sites, Research in Brief, 1996, NCJ 157108.

\section{DNA}

Connors, Edward, Thomas Lundregan, Neal Miller, and Tom McEwen, Convicted by Juries, Exonerated by Science: Case Studies in the Use of DNA Evidence to Establish Innocence After Trial, Research Report, 1996, NCJ 161258.

Hammond, Holly A., and C. Thomas Caskey, Automated DNA Typing: Method of the Future?, Research Preview, 1997, FS 000163. 
U.S. Department of Justice Office of Justice Programs 810 Seventh Street N.W. Washington, DC 20531

\section{Janet Reno}

Attorney General

U.S. Department of Justice

Raymond C. Fisher

Associate Attorney General

Laurie Robinson

Assistant Attomey General

Jeremy Travis

Director, National Institute of Justice

Justice Information Center

World Wide Web Site

http://www.ncjrs.org

National Institute of Justice

World Wide Web Site

http://www.ojp.usdoj.gov/nij/ 